\title{
発光バクテリアを用いた重金属等の土㙞污染簡易評価手法の開発 一急性毒性評価による土壤污染濃度のスクリーニングー*
}

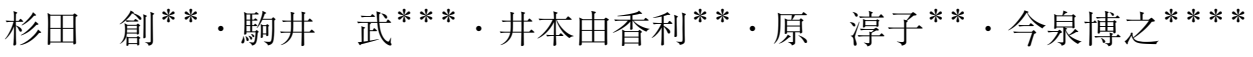 \\ Development of simplified evaluation method \\ on heavy metals soil pollution using luminous bacteria \\ -Screening method for soil pollution concentration \\ utilizing acute toxicity evaluation-
}

\author{
Hajime SUGITA**, Takeshi KOMAI***, Yukari IMOTO**, \\ Junko HARA** and Hiroyuki IMAIZUMI****
}

\begin{abstract}
In Japan, 9 heavy metals $\left(\mathrm{Cd}, \mathrm{Pb}, \mathrm{Hg}\right.$, Se, $\mathrm{Cr}^{6+}$, $\left.\mathrm{As}, \mathrm{F}, \mathrm{B}, \mathrm{CN}\right)$ have been regulated as Class II Specified Chemical Substances in the Soil Contamination Countermeasures Act. In this study, these 9 heavy metals were examined by an acute toxicity test using luminous bacteria (Vibrio fischeri). Then the availability of the method proposed by us as soil pollution evaluation method was considered empirically. In the result, it was shown that the method is available as the screening method for soil pollution based on the soil content reference values as for 7 heavy metals $\left(\mathrm{Cd}, \mathrm{Pb}, \mathrm{Hg}, \mathrm{Cr}^{6+}, \mathrm{As}, \mathrm{Se}, \mathrm{B}\right)$. Also, the correlation between the degree of acute toxicity effects on the luminous bacteria and each concentration of heavy metals $\left(\mathrm{Cd}, \mathrm{Pb}, \mathrm{Hg}, \mathrm{Cr}^{6+}\right.$, As, Se) was clarified and quantified. It could allow the quantitative evaluation of the soil pollution by each of these 6 heavy metals.
\end{abstract}

Key Words: soil pollution evaluation method, bioassay, luminous bacteria, heavy metals, Soil Contamination Countermeasures Act

本論文の一部は, 第46回地盤工学研究発表会, 第20回環境化学討論会, 第21回環境化学討論会, 平成24年度資源・素 材関倸学協会合同秋季大会, 日本地下水学会2012年秋季講演会に扔いて発表した。

** (独) 産業技術総合研究所 地圈資源環境研究部門（テ305-8567 茨城県つくば市東1-1-1）

Institute for Geo-Resources and Environment, National Institute of Advanced Industrial Science and Technology

*** 東北大学大学院 環境科学研究科

Graduate School of Environmental Studies, Tohoku University

****（独）産業技術総合研究所 企画本部

Planning Headquarters, National Institute of Advanced Industrial Science and Technology 


\section{要 旨}

本研究では, 土壤污染対策法の第二種特定有害物質として指定されている重金属等 9 物質 $(\mathrm{Cd}$, $\mathrm{Pb}, \mathrm{Hg}, \mathrm{Se}, \mathrm{Cr}^{6+}, \mathrm{As}, \mathrm{F}, \mathrm{B}, \mathrm{CN}$ ) に対して発光バクテリア（Vibrio fischeri）による急性毒性試 験を実施し, 本手法の土壤污染評価手法としての有効性を検討した。 $\mathrm{Cd}, \mathrm{Pb}, \mathrm{Hg}, \mathrm{Cr}^{6+}, \mathrm{As}, \mathrm{Se}$ 及び B について，本手法が土壤含有量基準值に基づく土壤污染のスクリーニングに利用できること を示した。さらに, $\mathrm{Cd}, \mathrm{Pb}, \mathrm{Hg}, \mathrm{Cr}^{6+}$, As 及び Se の各濃度と急性毒性影響との間に相関性を見出し, その定量化を行うことによって,これら 6 種による個々の土䁃污染の定量評価を可能とした。

キーワード：土壤污染評価，バイオアッセイ，発光バクテリア，重金属等，土壤污染対策法

\section{1. はじめに}

近年, 先進諸国をはじめ, アジアや南アメリカ などの発展途上国でも重金属等や揮発有機塩素化 合物等による土䁃污染が顕在化しており, 社会的 にも土壤污染の調查・対策等が求められている。 日本国内においても,「土壤污染対策法」が平成 14年に制定されており，この法律によって規制さ れている污染物質は「水質污濁防止法」によって 規制されたものに準じている。この法律の中で污 染物質は，3種類に区分されており，第一種特定 有害物質として揮発性有機化合物, 第二種特定有 害物質として重金属等, 第三種特定有害物質とし て PCB ・農薬等が指定されている。なお, 第二種 有害物質として指定されている物質は表 1 に記載 されている 9 物質 (カドミウム $\mathrm{Cd}$, 六価クロム $\mathrm{Cr}^{6+}$, シアン $\mathrm{CN}$, 水銀 $\mathrm{Hg}$, セレン $\mathrm{Se}$, 鉛 $\mathrm{Pb}$, 砒 素 As，ふっ素 $\mathrm{F}$ ，ほう素 $\mathrm{B}$ ）である。これらを総 称して「重金属類」と呼称する場合も多いが, 本

\section{表 1 土壌污染対策法における第二種特定有害物 質の指定基準値}

Table 1 Specified reference values of Class II Specified Chemical Substances in the Soil Contamination Countermeasures Act

\begin{tabular}{|l|l|l|}
\hline \multicolumn{1}{|c|}{ 第二種特定有害物質 } & \multicolumn{1}{|c|}{ 土滾溶出量基準 } & \multicolumn{1}{|c|}{ 土壌含有量基準 } \\
\hline カドミウム及びその化合物 & $0.01 \mathrm{mg} / \mathrm{L}$ 以下 & $150 \mathrm{mg} / \mathrm{kg}$ 以下 \\
\hline 六価クロム化合物 & $0.05 \mathrm{mg} / \mathrm{L}$ 以下 & $250 \mathrm{mg} / \mathrm{kg}$ 以下 \\
\hline シアン化合物 & 検出されないこと & $\begin{array}{l}\text { 遊離シアンとして } \\
\mathrm{mg} / \mathrm{kg} \mathrm{以下}\end{array}$ \\
\hline 水銀及びその化合物 & $\begin{array}{l}0.0005 \mathrm{mg} / \mathrm{L} \text { 以下、かつ、アル } \\
\text { キル水銀が検出されないこと }\end{array}$ & $15 \mathrm{mg} / \mathrm{kg}$ 以下 \\
\hline セレン及びその化合物 & $0.01 \mathrm{mg} / \mathrm{L}$ 以下 & $150 \mathrm{mg} / \mathrm{kg}$ 以下 \\
\hline 鉛及びその化合物 & $0.01 \mathrm{mg} / \mathrm{L}$ 以下 & $150 \mathrm{mg} / \mathrm{kg}$ 以下 \\
\hline 砒素及びその化合物 & $0.01 \mathrm{mg} / \mathrm{L}$ 以下 & $150 \mathrm{mg} / \mathrm{kg}$ 以下 \\
\hline ふっ秦及びその化合物 & $0.8 \mathrm{mg} / \mathrm{L}$ 以下 & $4,000 \mathrm{mg} / \mathrm{kg}$ 以下 \\
\hline ほう素及びその化合物 & $1 \mathrm{mg} / \mathrm{L}$ 以下 & $4,000 \mathrm{mg} / \mathrm{kg}$ 以下 \\
\hline
\end{tabular}

研究においては土潩污染対策法の用語に合わせる ために, 第二種特定有害物質を「重金属等」と表 記する。

一方, 水質分野では, 有害物質の毒性を総合的 に判断する方法として, メダカやミジンコ等微小 生物を用いたバイオアッセイ（生物学的毒性試 験）がこれまでにも行われてきたが, 最近では, 発光バクテリアを用いたバイオアッセイが, 有害 物質の急性毒性評価や污染物質の簡易検出技術 として注目されている。これは代謝によって発光 する特殊なバクテリアの性質を利用して, その発 光強度の減少量あるいは減少速度によって污染 物質の毒性を検知・評価する手法である。日本国 内においても発光バクテリアを用いて毒性評価 を行った実施例が報告されている（例えば，国立 環境研究所, 1998, 2001, 2006; 山川ほか, 1998 ; 北橋, 2000, 2001；笹島ほか, 2005, 2006 ; 荒川 ほか, 2007a, 2007b)。特に海洋性発光バクテリア の一種である「Vibrio fischeri（ビブリオ・フィッ シェリ)」は急性毒性試験等に広く使われてお り, 国際標準化機構 (International Organization for Standardization, 略称 ISO) によって, ISO 11348-1 : 2007, ISO 11348-2 : 2007, ISO 113483:2007, ISO 21338:2010として規格化されている。

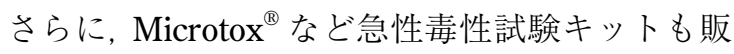
売され, McFeters et al. (1983) や Codina et al. (1994), McCloskey et al. (1996), Gallert (1999), Mowat and Bundy (2002), Heseih et al. (2004), Fulladosa et al. (2005) など多くの研究者によっ て Microtox ${ }^{\circledR}$ を使用した重金属等の急性毒性試験 の結果が報告されている。また, 多くの有害物質 の毒性值を概略的にまとめたデータインデックス も報告されている（Kaiser and Palabrica, 1991）。 しかしながら, 有害物質に暴露されてからの発光 
バクテリアの発光強度の経時変化に関する詳細な 研究報告はほとんどなく，また，有害物質の種類 やその濃度と発光バクテリアに及ぼす急性毒性の 強さの相関関係について定量的にまとめた信頼性 の高い試験データ自体が極めて少ないため, 実際 に定量評価を行うに足るデータベース等は整備さ れていないのが現状である。それゆえ, 発光バク テリアに及ぼす各種有害物質の急性毒性の強さを 定量評価し, 急性毒性の強さから有害物質の濃度 を概算することを可能にするための各種パラメー 夕值の取得が望まれている。

また, 水質分野で注目されている発光バクテリ アによる有害物質の急性毒性評価試験を土壤污染 分野へ応用するためには, 土壇抽出液を検液とし た試験方法を想定した評価手法の確立が必要で あり, 種々の污染物質に対する急性毒性影響の闇 值, つまり定量下限值の確認や, 急性毒性影響の 大きさから土䁃の污染濃度を逆推算するために, 急性毒性影響と污染物質の濃度との相関性に関す る詳細な検討が必要不可欠である。

そこで, 本研究では, 第二種有害物質として指 定されている重金属等 9 種に着目して, 発光バク テリア（Vibrio fischeri）を用いて, 系統的なバイ オアッセイ試験を実施し, 得られたデータを基に 詳細な解析を行い, これら重金属等の検出性につ いての検討や各種重金属等の濃度と急性毒性の強 さとの相関関係の定量化を試み, さらに現場での 本手法の適用方法についても詳細に論じた。

\section{2. 実験方法}

\section{1 実験試薬}

\section{(1) 発光バクテリア}

本研究に用いた発光バクテリアの種類は, Vibrio fischeri であり, 日立化成株式会社から提供 を受けたものである。試験 1 回分の試薬として, この発光バクテリアがプラスチック容器に約 $1 \mathrm{~g}$ (塩溶液を含む) 入れられて冷凍保存されている。 なお,「Vibrio fischeri」は Urbanczyk et al. (2007) の研究によって「Aliivibrio fischeri」として再分 類されているが, 現在でも一般的な呼称としては $\lceil$ Vibrio fischeri」の方が広く普及しているため, 本研究でも「Aliivibrio fischeri」ではなく,「Vibrio fischeri」の呼称を使用することとする。

\section{（2）再活性化溶液}

再活性化溶液として $\mathrm{NaCl}$ 溶液（約 $0.3 \mathrm{~mol} / \mathrm{L}$ ) を所定量 $(25 \mathrm{~mL})$ 添加して発光バクテリアを解 凍することにより, 発光バクテリアは再活性化し 発光する。室温 $\left(20 \pm 5{ }^{\circ} \mathrm{C}\right)$ による解凍では, 再 活性化溶液添加後, 30分程度で発光バクテリアの 発光強度は最大值を取り, 検液を添加しない場合 には約 2 時間程度そのまま高い発光強度值を維持 した。

\section{（3）検液の調製}

各重金属等を含む検液の作成には, 表 2 に記し た和光純薬工業株式会社から購入した試薬を用い た。なお, 六価クロムについては, 溶存形態の違 いによる影響を調べるためにクロム酸塩と二クロ ム酸塩の 2 種類の試薬を用いた。また, 砒素及び セレンについては価数の違いによる影響を調べる ために, 砒素については三価及び五価, セレンに ついては四価及び六価の試薬をそれぞれ用いた。

これら粉末試薬及び液体試薬をイオン交換水で 溶解・希釈して任意の濃度の検液を準備した。な お, これらの検液は水酸化ナトリウム溶液または 塩酸を適量加えて $\mathrm{pH}$ を～9の間になるように 調整されている。これは, 検液の $\mathrm{pH}$ が $4 \sim 9$ の 範囲ならば, 本試験条件では $\mathrm{pH}$ の違いによる発 光バクテリアの発光強度への影響がほとんどない ことが予備試験によって確認されているためであ る。なお, ISO11348によれば, 発光バクテリア溶

表 2 検液の調製用試薬及び調整 $\mathrm{pH}$

Table 2 Reagents for preparing test solutions and examples of $\mathrm{pH}$ of test solutions

\begin{tabular}{|c|c|c|c|}
\hline 対象物質 & 検液調製用試薬 & $\mathrm{pH}$ 調整液 & 検液の $\mathrm{pH}$ の実測値の例 \\
\hline $\mathrm{Cd}$ & $\mathrm{Cd}\left(\mathrm{NO}_{3}\right)_{2}$ in $\mathrm{HNO}_{3}$ & \multirow{12}{*}{$\mathrm{NaOH}$ and $\mathrm{HCl}$} & $\mathrm{pH}$ of $500 \mathrm{mg} / \mathrm{L}$ was 6.8 \\
\hline $\mathrm{Pb}$ & $\mathrm{Pb}\left(\mathrm{NO}_{3}\right)_{2}$ in $\mathrm{HNO}_{3}$ & & $\mathrm{pH}$ of $500 \mathrm{mg} / \mathrm{L}$ was 7.0 \\
\hline $\mathrm{Hg}$ & $\mathrm{HgCl}_{2}$ in $\mathrm{HNO}_{3}$ & & $\mathrm{pH}$ of $\quad 10 \mathrm{mg} / \mathrm{L}$ was 5.5 \\
\hline $\mathrm{CN}$ & $\mathrm{NaCN}$ in Water & & $\mathrm{pH}$ of $\quad 10 \mathrm{mg} / \mathrm{L}$ was 5.5 \\
\hline $\mathrm{F}$ & $\mathrm{NaF}$ in Water & & $\mathrm{pH}$ of $500 \mathrm{mg} / \mathrm{L}$ was 6.9 \\
\hline B & $\mathrm{H}_{3} \mathrm{BO}_{3}$ in Water & & $\mathrm{pH}$ of $500 \mathrm{mg} / \mathrm{L}$ was 5.4 \\
\hline \multirow{2}{*}{$\mathrm{Cr}^{6+}$} & $\mathrm{CaCrO}_{4}$ in Water & & $\mathrm{pH}$ of $500 \mathrm{mg} / \mathrm{L}$ was 6.3 \\
\hline & $\mathrm{K}_{2} \mathrm{Cr}_{2} \mathrm{O}_{7}$ in $\mathrm{HNO}_{3}$ & & $\mathrm{pH}$ of $500 \mathrm{mg} / \mathrm{L}$ was 5.0 \\
\hline $\mathrm{As}^{3+}$ & $\mathrm{NaAsO}_{2}$ in Water & & $\mathrm{pH}$ of $\quad 10 \mathrm{mg} / \mathrm{L}$ was 6.3 \\
\hline $\mathrm{As}^{5+}$ & $\mathrm{Na}_{2} \mathrm{HAsO}_{4} \cdot 7 \mathrm{H}_{2} \mathrm{O}$ in Water & & $\mathrm{pH}$ of $\quad 10 \mathrm{mg} / \mathrm{L}$ was 7.1 \\
\hline $\mathrm{Se}^{4+}$ & $\mathrm{H}_{2} \mathrm{SeO}_{3}$ in $\mathrm{HNO}_{3}$ & & $\mathrm{pH}$ of $500 \mathrm{mg} / \mathrm{L}$ was 7.2 \\
\hline $\mathrm{Se}^{6+}$ & $\mathrm{Na}_{2} \mathrm{SeO}_{4}$ in Water & & $\mathrm{pH}$ of $500 \mathrm{mg} / \mathrm{L}$ was 6.5 \\
\hline
\end{tabular}


液の望ましい $\mathrm{pH}$ 範囲は6.0〜8.5とされており, 後述するように, 本研究では発光バクテリア溶液 $1 \mathrm{~mL}$ に対して検液50 $\mu \mathrm{L}$ を添加しているので, 発 光バクテリア溶液へ添加した検液は 21 倍希釈され ることになるため, 検液添加による $\mathrm{pH}$ の変動に よる発光強度への影響はなかったと推測される。 また, ナトリウムイオン, 塩化物イオン, 硝酸イ オン及び硫酸イオンについても検液中の濃度がそ れぞれ $1 \mathrm{~mol} / \mathrm{L}$ 程度までならば発光バクテリアの 発光強度にほとんど影響を及ぼさないことも同様 に予備試験によって確認している。つまり, 検液 調製用の試薬としてナトリウム塩, 塩化物, 硝酸 塩, 硫酸塩を使用した場合, 試験対象物質以外の 不純物として検液中にナトリウムイオン, 塩化物 イオン, 硝酸イオンあるいは硫酸イオンが存在す るが, これら諸溶存イオンによる発光バクテリア の発光強度に及ぼす影響は無視できる。

\section{2 測定方法}

本研究における発光バクテリアによる急性毒性 試験フローの概略を図 1 に示す。24試料を同時測 定可能なルミノメーター（RT01, 日立化成株式 会社）で発光バクテリアの発光強度を測定した。 再活性化約45分後の発光バクテリア溶液を各セル に1 mLずつ取り, 発光強度を測定し, その值を初

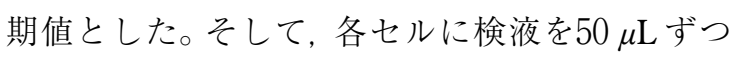
添加し, 直ちに発光強度を連続測定して経時変化 を記録した。この測定開始時刻を検液と発光バク
テリアとの反応開始時間と見なすこととする。ま た, 同一検液を 3 つのセルに添加し, その平均值 をデー夕解析に使用した。なお, 本試験における 測定誤差は概ね 5 \%以内であった。

\section{3 毒性評価方法}

ブランクとしてイオン交換水を加えたセルの 発光バクテリアのある時間での発光強度 $I_{\mathrm{Blank}}$ を そのセルの発光強度の初期值 $I_{\mathrm{Blank} 0}$ で割った值 $\left(I_{\text {Blank }} / I_{\text {Blank0 } 0}\right)$ を基準として, 物質 $\mathrm{X}$ を含む検液を 加えたセルの発光バクテリアのある時間での発光 強度 $I_{\mathrm{X}}$ をそのセルの発光強度の初期值 $I_{\mathrm{X} 0}$ で割っ た值 $\left(I_{\mathrm{X}} / I_{\mathrm{X} 0}\right)$ を相対評価することによって，その 物質 $\mathrm{X}$ の発光バクテリアに及ぼす影響力を評価 する。つまり, 次式で表される発光バクテリアの 相対発光強度比 $S[\%]$ の值を指標とする。

$$
S=\left(I_{\mathrm{X}} / I_{\mathrm{X} 0}\right) /\left(I_{\text {Blank }} / I_{\text {Blank } 0}\right) \times 100
$$

したがって, $S$ の值が小さいほど毒性影響が大き いことになる。

\section{3. 急性毒性試験結果}

\section{3. $1 \mathrm{Cd}, \mathrm{Pb}, \mathrm{Hg}, \mathrm{CN}, \mathrm{F}, \mathrm{B}$ に関する急性毒 性試験の結果}

$\mathrm{Cd}, \mathrm{Pb}, \mathrm{Hg}, \mathrm{CN}, \mathrm{F}, \mathrm{B}$ に関する試験結果を図 2 (a) 〜 (f) にそれぞれ示す。なお, 溶液中では

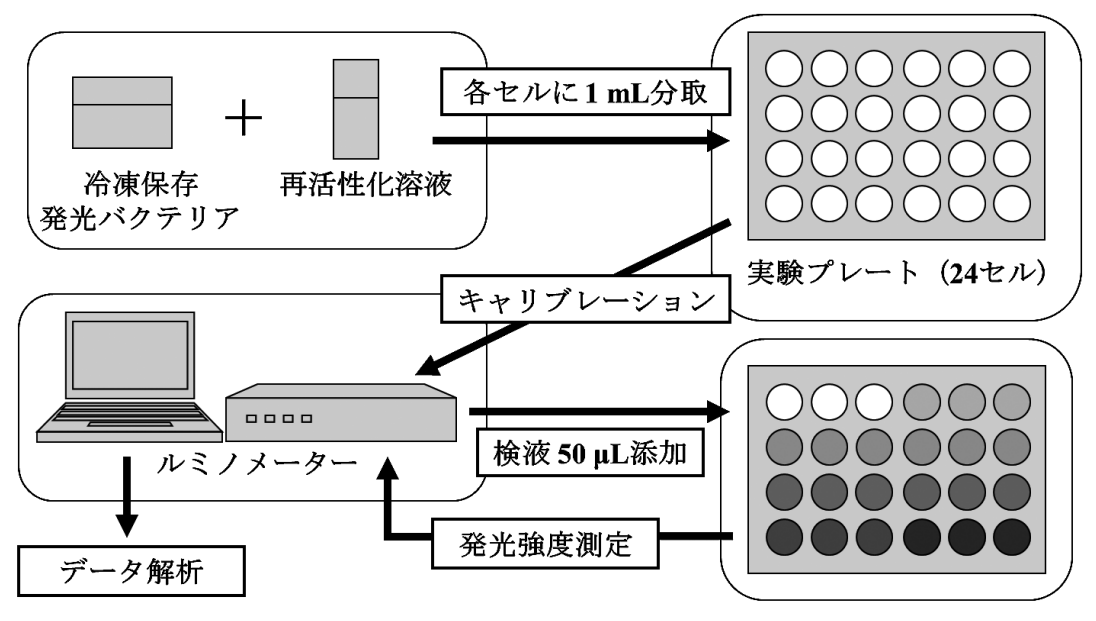

図 1 発光バクテリアによる急性毒性試験フロー

Fig. 1 Experimental flow for acute toxicity test using luminous bacteria 
それぞれ主として $\mathrm{Cd}^{2+}, \mathrm{Pb}^{2+}, \mathrm{Hg}^{2+}, \mathrm{CN}^{-}, \mathrm{F}^{-}$, $\mathrm{B}(\mathrm{OH})_{3}$ の形で溶存していると考えられる。これ らの図は, 横軸に曝露時間 $t$, 縦軸に検液添加後 の発光バクテリアの相対発光強度比 $S$ を示した ものである。

$\mathrm{Cd}, \mathrm{Pb}, \mathrm{Hg}$ を発光バクテリア溶液に添加した 試験では，ほとんどの場合，時間の経過に伴い $S$ は減少し,また $S$ の減少度合いは各重金属等の濃 度が高くなるほど大きくなっている（図 2 (a), (b), (c))。つまり, $\mathrm{Cd}, \mathrm{Pb}, \mathrm{Hg}$ は発光バクテリ
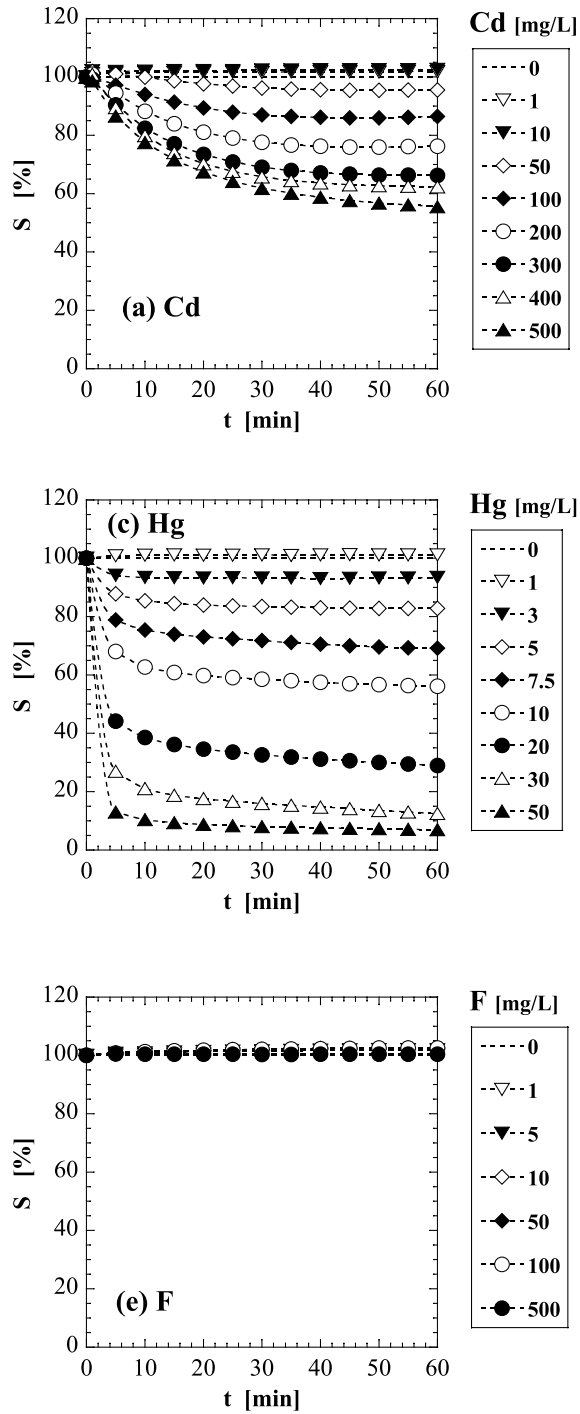

アに対して急性毒性を示し, その毒性の強さには 濃度依存性があることがわかる。CN を発光バク テリア溶液に添加した場合, 前述の重金属等とは 逆に, 添加した検液中の $\mathrm{CN}$ 濃度が高いものほど $S$ の值も高くなっている（図 $2(\mathrm{~d}))$ 。このことか ら, CN は発光バクテリアを活性化する作用があ ると考えられる。一方, F は本試験の濃度範囲 (検 液中の濃度として $1 \sim 500 \mathrm{mg} / \mathrm{L}$ ) では, 発光バク テリアの発光強度に全く影響を及ぼさず, 測定時 間内において $S$ の值はほぼ100\%のままであった
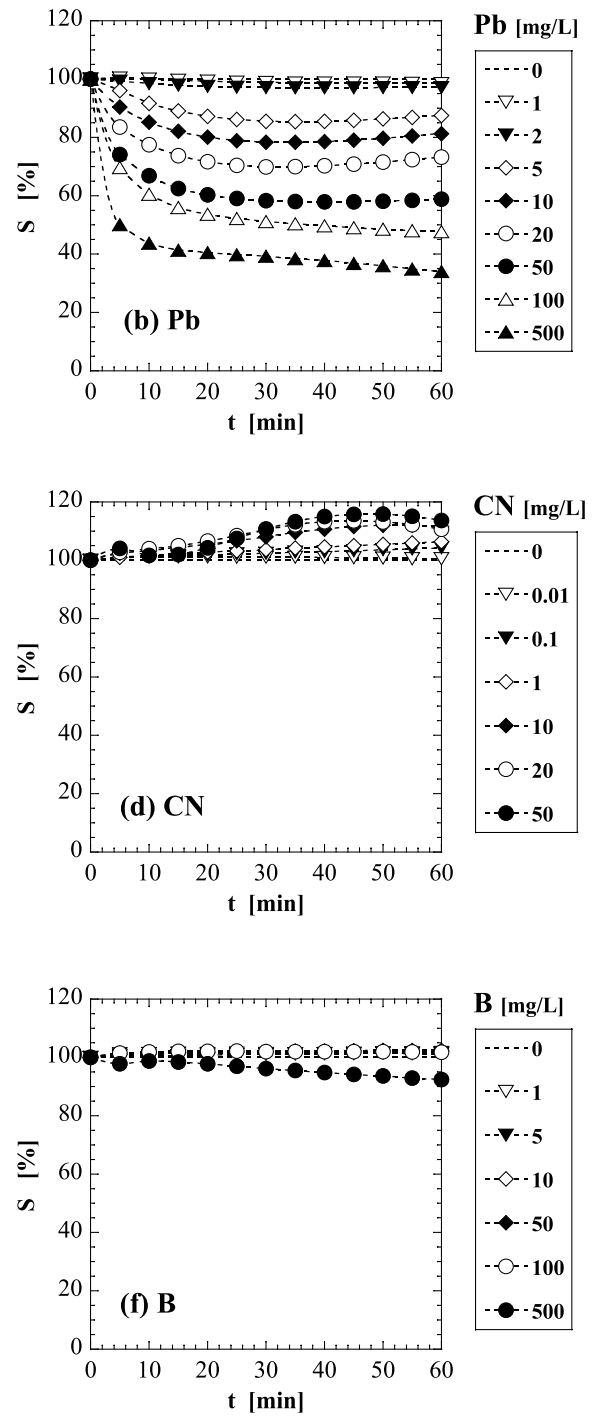

図 2 発光バクテリアの相対発光強度比の経時変化 : (a) Cd, (b) Pb, (c) Hg, (d) CN, (e) F, (f) B

Fig. 2 Change of relative luminescence intensity ratio of luminous bacteria with time: (a) $\mathrm{Cd}$, (b) $\mathrm{Pb}$, (c) $\mathrm{Hg}$, (d) $\mathrm{CN},(e) \mathrm{F}$ and (f) B 
(図 2 (e) )。B も500 mg/L という極めて高い濃度 を持つ検液を添加した場合には $S$ に若干の低下が 認められるが, $100 \mathrm{mg} / \mathrm{L}$ まで発光バクテリアの 発光強度に全く影響を及ぼさなかった (図 $2(\mathbf{f}))$ 。 したがって，F 及び B は発光バクテリアに急性毒 性影響をほとんど与えないと考えてよいと思われ る。

\section{2 六価クロム $\mathrm{Cr}^{6+}$ に関する急性毒性試験 の結果}

六価クロム $\mathrm{Cr}^{6+}$ に関する試験結果を図 3 に示 す。図 3 (a) 及び（b）は, クロム酸塩及び二ク ロム酸塩から作成した溶液を検液とした試験結果 をそれぞれ示している。日本化学会（2004）によ ると, クロム酸 $\mathrm{H}_{2} \mathrm{CrO}_{4}$ の解離定数は $\mathrm{pKa}_{1}=1.67$, $\mathrm{pKa}_{2}=6.02$ であることから, 図 3 (a) における主 要な溶存クロム種は $\mathrm{HCrO}_{4}{ }^{-}$及び $\mathrm{CrO}_{4}{ }^{2-}$ であると 考えられる。また, 図3（a）及び（b）の検液は それぞれクロム酸塩及び二クロム酸塩から作成さ れているが, 下記の反応により, 溶液中でクロム 酸イオン種と二クロム酸イオン種は化学平衡状態 にあると考えられる。なお, 当該論文で使用した pKaの各值は, 日本化学会（2004）の表11.1から の引用である。

$$
\begin{gathered}
2 \mathrm{HCrO}_{4}{ }^{-} \Leftrightarrow \mathrm{Cr}_{2} \mathrm{O}_{7}{ }^{2-}+\mathrm{H}_{2} \mathrm{O} \\
\mathrm{pKa}=2.05 \\
2 \mathrm{CrO}_{4}{ }^{2-}+3 \mathrm{H}^{+} \Leftrightarrow \mathrm{HCr}_{2} \mathrm{O}_{7}^{-}+\mathrm{H}_{2} \mathrm{O} \\
\mathrm{pKa}=13.9
\end{gathered}
$$

$$
\begin{aligned}
& 2 \mathrm{CrO}_{4}{ }^{2-}+2 \mathrm{H}^{+} \Leftrightarrow \mathrm{Cr}_{2} \mathrm{O}_{7}{ }^{2-}+\mathrm{H}_{2} \mathrm{O} \\
& \mathrm{pKa}=15.7
\end{aligned}
$$

上記の式から明らかなように, クロム酸イオン 種と二クロム酸イオン種の濃度は, $\mathrm{pH}$ と $\mathrm{Cr}$ 濃度 に依存するが, $\mathrm{pH}$ 調整後のクロム酸検液及び二 クロム酸検液の色相は, それぞれ薄黄色及び薄橙 赤のままであったことから, 実際には図 3 (a) に 示した試験ではクロム酸イオン種が, 図 $3(\mathrm{~b}) に$ 示した試験では二クロム酸イオン種が優勢であっ たと思われる。このことから, 便宜上, 図 $3(\mathrm{a})$ はクロム酸イオン $\left(\mathrm{CrO}_{4}{ }^{2-}\right)$ の影響を, 図 $3(\mathrm{~b})$ は二クロム酸イオン $\left(\mathrm{Cr}_{2} \mathrm{O}_{7}{ }^{2-}\right)$ の影響をそれぞ れ示していると見なすこととする。

図 3 から, クロム酸イオン及び二クロム酸イ オンともに検液濃度が $10 \mathrm{mg} / \mathrm{L}$ 程度まで発光バ クテリアに対して急性毒性影響を与えないが, $50 \mathrm{mg} / \mathrm{L}$ 以上では曝露時間 60 分で $S$ は $95 \%$ 以下 となっており, 測定誤差を加味しても明らかな急 性毒性影響を示している。また, その毒性の強さ には濃度依存性があることがわかる。そして, 眓 3（a）と（b）において同じ $\mathrm{Cr}$ 濃度における $S$ の值を比較すると, おおよその全体的な傾向とし てはクロム酸イオンよりも二クロム酸イオンの方 が低くなっており, 特に反応初期の $S$ の減少速度 は, クロム酸イオンよりも二クロム酸イオンの方 が顕著に高いように見える。しかしながら, 二ク ロム酸イオンを添加した発光バクテリア溶液で は, 反応初期の減少速度は高いが, 時間の経過に 伴い $S$ の減少は極めて緩やかになり, 曝露時間30 分と60分における $S$ の值にはほとんど差異は認

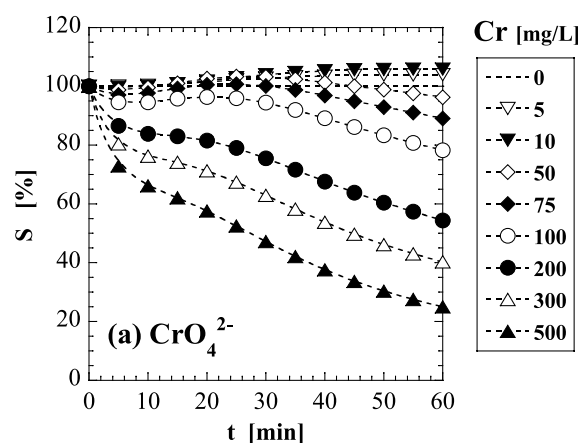

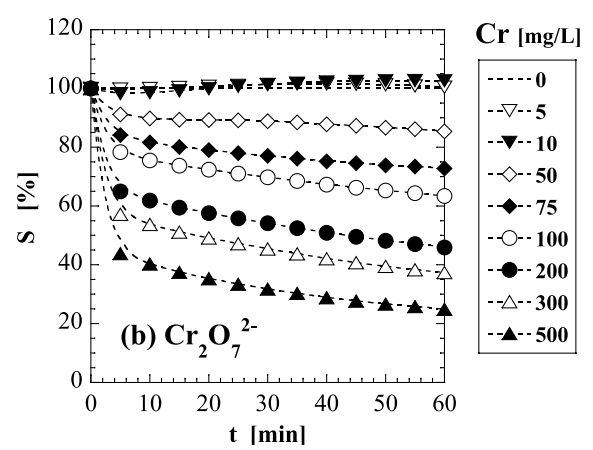

図 3 発光バクテリアの相対発光強度比の経時変化 : (a) $\mathrm{CrO}_{4}{ }^{2-}$, (b) $\mathrm{Cr}_{2} \mathrm{O}_{7}{ }^{2-}$

Fig. 3 Change of relative luminescence intensity ratio of luminous bacteria with time: (a) $\mathrm{CrO}_{4}{ }^{2-}$ and (b) $\mathrm{Cr}_{2} \mathrm{O}_{7}{ }^{2-}$ 
められない。一方, クロム酸イオンを添加した発 光バクテリア溶液では, 反応初期の減少速度は低 いが, 時間が経過してもSの減少は続き, 曝露時 間30分と60分における $S$ の值に大きな差異が認 められる。これらの結果から, 曝露時間がさらに 長くなれば, Cr 濃度が同じ場合, クロム酸イオン と二クロム酸イオンの間で $S$ の值に大きな差異 は無くなることが予想される。これは, 前述した ようにクロム酸イオンと二クロム酸イオンが溶液 中において化学平衡状態で共存するが, 実際には 平衡に達するまでにある程度の時間を要し, 平衡 状態になったときの存在比は, $\mathrm{pH}$ と初期 $\mathrm{Cr}$ 濃度 に依存するためと考えられる。

\section{3 砒素 As に関する急性毒性試験の結果}

砒素Asに関する試験結果を図 4 に示す。図 4 (a) 及び（b）は，三価砒素（亜ヒ酸塩）及び五 価砒素（七酸塩）の影響をそれぞれ示している。 なお，亜七酸の第一酸解離定数 $\mathrm{pKa}_{1}$ が9.14である ことから, 本試験条件では, 図 4（a）における三 価砒素の支配的な溶存形態としては, $\mathrm{As}(\mathrm{OH})_{3}$ が 予想される。一方, 七酸の酸解離定数が $\mathrm{pKa}_{1}=$ 2.24, $\mathrm{pKa}_{2}=6.94, \mathrm{pKa}_{3}=11.50$ であることから, 図 4 (b) における五価砒素の支配的な溶存形態 としては, ヒ酸二水素イオン $\mathrm{H}_{2} \mathrm{AsO}_{4}{ }^{-}$あるいはヒ 酸水素イオン $\mathrm{HAsO}_{4}{ }^{2-}$ が予想される。なお, 本試 験は特殊な好気・嫌気条件下での実験ではなく, また, 酸化剂や還元剂として働く特別な物質も存 在していないので, 砒素の価数の変化を伴う迅速 な酸化還元反応が生じるとは考えにくい。そのた め, 本試験における砒素の価数の変化は無視でき
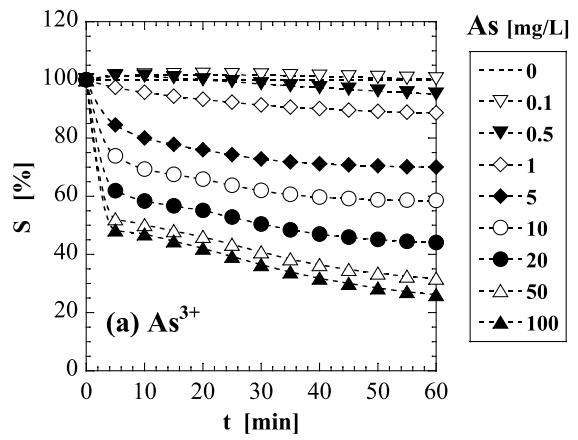

るものとする。

図 4 から, 三価砒素及び五価砒素ともに検液濃 度が $0.1 \mathrm{mg} / \mathrm{L}$ 程度まで発光バクテリアに対して 急性毒性影響を与えないが, $1 \mathrm{mg} / \mathrm{L}$ 以上で明ら かな急性毒性影響を示し, その毒性の強さには濃 度依存性があることがわかる。全体的な傾向とし ては, 三価砒素を添加した発光バクテリア溶液で は, 曝露時間 $0 \sim 10$ 分程度までの減少速度は五価 砒素の場合と比較して幾分低いが，曝露時間が20 分以上経過しても $S$ の減少は続き, 曝露時間30分 と60分における $S$ の值には明らかな差異が認め られる。一方, 五価砒素を添加した発光バクテリ ア溶液では, 曝露時間 0 １0分程度までの減少速 度は三価砒素を添加した場合よりも幾分高いが, 曝露時間20分以降 $S$ はほとんど変動していない。 一般に, 七酸（五価砒素）よりも亜七酸（三価砒 素）の方が毒性が高いとされているが, 図 4 (a) と（b）における同じAs 濃度における $S$ の值の 比較からは, 一概にどちらの毒性が高いとは判断 できない。しかしながら，Sの初期（曝露時間 0 10分程度）の減少速度に着目するならば, 発光バ クテリアに及ぼす急性毒性影響は, 亜ヒ酸（三価 砒素）よりも七酸（五価砣素）の方が大きいよう に見える。

\section{4 セレン Se に関する急性毒性試験の結果}

セレン Se に関する試験結果を図 5 に示す。図 5（a）及び（b）は，四価セレン（亜セレン酸 塩）及び六価セレン (セレン酸塩) の影響をそれ ぞれ示している。なお, 亜セレン酸の酸解離定数 が $\mathrm{pKa}_{1}=2.61, \mathrm{pKa}_{2}=8.05$ であことから, 図 5

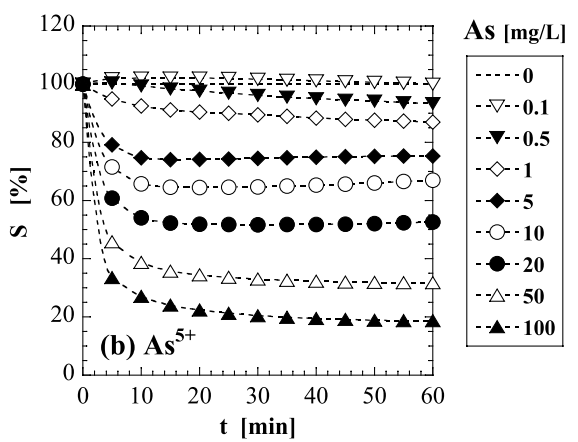

図 4 発光バクテリアの相対発光強度比の経時変化 : (a) $A s^{3+}$, (b) $A s^{5+}$

Fig. 4 Change of relative luminescence intensity ratio of luminous bacteria with time: (a) $A s^{3+}$ and (b) $A s^{5+}$ 

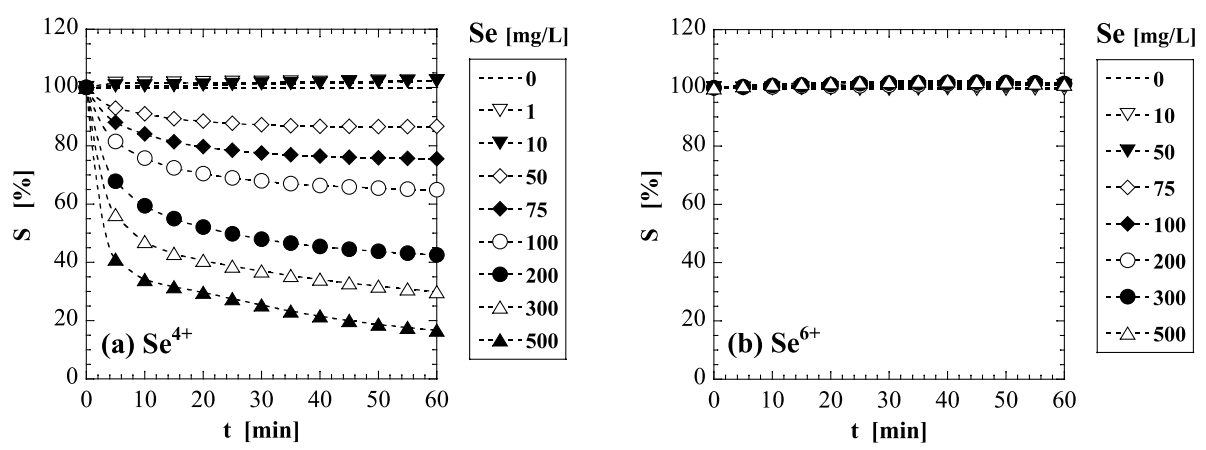

図 5 発光バクテリアの相対発光強度比の経時変化 : (a) $\mathrm{Se}^{4+}$, (b) $\mathrm{Se}^{6+}$

Fig. 5 Change of relative luminescence intensity ratio of luminous bacteria with time: (a) $\mathrm{Se}^{4+}$ and (b) $\mathrm{Se}^{6+}$

(a)における四価セレンの支配的な溶存形態とし ては, 亜セレン酸水素イオン $\mathrm{HSeO}_{3}{ }^{-}$が予想され る。一方, セレン酸は強酸であり, 第二酸解離定 数 $\mathrm{pKa}_{2}$ が1.7程度であることから, 図 5 (b) にお ける六価セレンの支配的な溶存形態としては, セ レン酸イオン $\mathrm{SeO}_{4}{ }^{2-}$ が予想される。また, 本試験 条件では, 砒素の場合と同様にセレンの価数の変 化を伴う迅速な酸化還元反応が生じるとは考えに くいため, 当該急性毒性試験におけるセレンの価 数の変化は無視できるものとする。

図 5 から明らかなように, 四価セレンは発光バ クテリアに対して急性毒性を示し, 濃度が高くな るほど毒性も高くなっているが, 六価セレンは発 光バクテリアに対して急性毒性を全く示さなかっ た。2．1（3）で述べたように, 予備試験によっ て硫酸イオンは発光バクテリアに対して急性毒 性影響を与えないことが確認されている。硫酸イ オンの化学構造は, 硫黄原子 S を中心とし, 4 つ の酸素原子 $\mathrm{O}$ を各頂点とする四面体構造である が, セレン酸イオンも硫酸イオン同様にセレン原 子 Se を中心とした 4 つの酸素原子 $\mathrm{O}$ を各頂点と する四面体構造であり，このことが無毒性に関係 しているかもしれないが, 明確な理由は不明であ る。

\section{5 発光バクテリアによる重金属等の検出性}

\section{（1）本試験条件での重金属等の検出限界値}

本研究では, 土壤污染対策法の土䁃溶出量試験 あるいは土壤含有量試験に準じて作成した土壤抽 出液を用いて, 発光バクテリアによる急性毒性試 験を実施することにより, 污染サイトのスクリー
表 3 本試験条件での重金属等の検出限界値 *

Table 3 Detection limits of heavy metals in the present test conditions

\begin{tabular}{|c|c|c|c|}
\hline 対象物質 & 予想される検出反応種の主形態 & $\mathrm{t}=60 \min$ & $\begin{array}{c}\text { 土袞含有量基準相当値 } \\
\text { (重量体稓比 3\%) }\end{array}$ \\
\hline $\mathrm{Cd}$ & カドミウムイオン : $\mathrm{Cd}^{2+}$ & $50 \sim 100 \mathrm{mg} / \mathrm{L}$ & $4.5 \mathrm{mg} / \mathrm{L}$ \\
\hline $\mathrm{Pb}$ & 鉛イオン: $\mathrm{Pb}^{2+}$ & $2 \sim 5 \mathrm{mg} / \mathrm{L}$ & $4.5 \mathrm{mg} / \mathrm{L}$ \\
\hline $\mathrm{Hg}$ & 水銀イオン: $\mathrm{Hg}^{2+}$ & $2 \sim 3 \mathrm{mg} / \mathrm{L}$ & $0.45 \mathrm{mg} / \mathrm{L}$ \\
\hline $\mathrm{CN}$ & シアンイオン : $\mathrm{CN}^{-}$ & 検出不能 & $1.5 \mathrm{mg} / \mathrm{L}$ \\
\hline $\mathrm{F}$ & ふっ素イオ : F- & 検出不能 & $120 \mathrm{mg} / \mathrm{L}$ \\
\hline B & ホウ酸イオン : $\mathrm{B}(\mathrm{OH})_{4}^{-}$ & $500 \mathrm{mg} / \mathrm{L}$ & $120 \mathrm{mg} / \mathrm{L}$ \\
\hline \multirow{2}{*}{$\mathrm{Cr}^{6+}$} & クロム酸イオン: $\mathrm{CrO}_{4}^{2-}$ & $50 \sim 75 \mathrm{mg} / \mathrm{L}$ & \multirow{2}{*}{$7.5 \mathrm{mg} / \mathrm{L}$} \\
\hline & ニクロム酸イオン: $\mathrm{Cr}_{2} \mathrm{O}_{7}^{2-}$ & $20 \sim 50 \mathrm{mg} / \mathrm{L}$ & \\
\hline $\mathrm{As}^{3+}$ & 亜七酸イオン: $\mathrm{H}_{2} \mathrm{AsO}_{3}{ }^{-}$ & $0.2 \sim 0.5 \mathrm{mg} / \mathrm{L}$ & \multirow{2}{*}{$4.5 \mathrm{mg} / \mathrm{L}$} \\
\hline $\mathrm{As}^{5+}$ & ヒ酸イオン: $\mathrm{HAsO}_{4}{ }^{2-}$ & $0.2 \sim 0.5 \mathrm{mg} / \mathrm{L}$ & \\
\hline $\mathrm{Se}^{4+}$ & 亜セレン酸イオン : $\mathrm{HSeO}_{3}^{-}$ & $10 \sim 50 \mathrm{mg} / \mathrm{L}$ & \multirow{2}{*}{$4.5 \mathrm{mg} / \mathrm{L}$} \\
\hline $\mathrm{Se}^{6+}$ & セレン酸イオン: $\mathrm{SeO}_{4}^{2-}$ & 検出不能 & \\
\hline
\end{tabular}

* 発光バクテリア溶液 $1 \mathrm{~mL}$ に対し検液 $50 \mu \mathrm{L}$ の場合の值である。

ニングや污染浄化過程における浄化の進行状況の 簡易評価に用いることを想定している。表 3 に本 試験結果に基づいた重金属等の検出限界值を示 す。通常, 土壤含有量基準の基準值は, 土壤単位 重量 $[\mathrm{kg}]$ あたりに含まれる污染物質の重量 $[\mathrm{mg}]$ で示されているが, 比較を容易にするために, 抽 出水中の污染物質濃度として換算した值である土 壤含有量基準相当值を表 3 に併せて記載した。こ の土壤含有量基準相当值よりも検出限界值が低け れば, 污染サイトのスクリーニングにも適用可能 であると考えらえるが, 確実に適合するのはAs のみで, 他の重金属等については, 表 1 に示され ている土壤溶出量基準值をクリアできるほど検出 性の高い物質は無かった。 


\section{（2）発光バクテリアに及ぼす重金属等の急性毒 性影響の閾値}

本研究では, 発光バクテリア溶液 $1 \mathrm{~mL}$ に対し て検液50 $\mu \mathrm{L}$ を添加しているため, 実際に発光強 度を測定している試料中の重金属等の濃度は検 液中の濃度の 21 分の 1 の值である。それゆえ, 検 出性の限界值を真に評価するには, 表 3 に記載さ れている濃度值の 21 分の 1 の值で議論すべきで ある。また, この濃度は発光バクテリアに急性毒 性影響を及ぼす各重金属等の閾值でもある。表 4 に本試験結果から得られた発光バクテリアに及 ぼす重金属等の急性毒性影響の閾值を示す。重金 属等の発光バクテリアに及ぼす急性毒性の闇值 は, $\mathrm{Cd}, \mathrm{CN}, \mathrm{F}$ 及び $\mathrm{Se}^{6+}$ を除けば土壤含有量基準 相当值を十分に下回っていることがわかる。つま り, 発光バクテリア溶液と検液の混合割合を調整 する等の工夫によって, $\mathrm{Cd}, \mathrm{CN}, \mathrm{F}$ 及び $\mathrm{Se}^{6+}$ 以外 の重金属等を検出することが可能であると考えら れる。また, 表 3 及び表 4 から重金属等の検出性 の高さは下記の順となる。

$$
\begin{aligned}
\mathrm{As}^{3+} & , \mathrm{As}^{5+}>\mathrm{Hg}, \mathrm{Pb}>\mathrm{Se}^{4+} \\
& >\mathrm{Cr}^{6+}\left(\text { as } \mathrm{Cr}_{2} \mathrm{O}_{7}{ }^{2-}\right)>\mathrm{Cr}^{6+}\left(\text { as }_{\mathrm{CrO}_{4}}{ }^{2-}\right), \mathrm{Cd}>\mathrm{B}
\end{aligned}
$$

\section{表 4 発光バクテリアに及ぼす重金属等の急性毒 性影響の閾値*}

Table 4 Threshold values for acute toxicity effect

\begin{tabular}{|c|c|c|c|}
\hline 対象物質 & 予想される検出反応種の主形態 & $t=60 \min$ & $\begin{array}{c}\begin{array}{c}\text { 土壤含有量基淮相当值 } \\
\text { (重量体積比 3\%) }\end{array} \\
\end{array}$ \\
\hline $\mathrm{Cd}$ & カドミウムイオン : $\mathrm{Cd}^{2+}$ & $2.4 \sim 4.8 \mathrm{mg} / \mathrm{L}$ & $4.5 \mathrm{mg} / \mathrm{L}$ \\
\hline $\mathrm{Pb}$ & 鉛イオン: $\mathrm{Pb}^{2+}$ & $0.095 \sim 0.24 \mathrm{mg} / \mathrm{L}$ & $4.5 \mathrm{mg} / \mathrm{L}$ \\
\hline $\mathrm{Hg}$ & 水銀イオン: $\mathrm{Hg}^{2+}$ & $0.095 \sim 0.14 \mathrm{mg} / \mathrm{L}$ & $0.45 \mathrm{mg} / \mathrm{L}$ \\
\hline $\mathrm{CN}$ & シアンイオン : $\mathrm{CN}^{-}$ & 急性毒性影響なし** & $1.5 \mathrm{mg} / \mathrm{L}$ \\
\hline F & ふっ素イオ： $\mathrm{F}^{-}$ & 急性毒性影響なし & $120 \mathrm{mg} / \mathrm{L}$ \\
\hline B & ホウ酸イオン : B $(\mathrm{OH})_{4}^{-}$ & $24 \mathrm{mg} / \mathrm{L}$ & $120 \mathrm{mg} / \mathrm{L}$ \\
\hline \multirow{2}{*}{$\mathrm{Cr}^{6+}$} & クロム酸イオン : $\mathrm{CrO}_{4}^{2-}$ & $2.4 \sim 3.6 \mathrm{mg} / \mathrm{L}$ & \multirow{2}{*}{$7.5 \mathrm{mg} / \mathrm{L}$} \\
\hline & ニクロム酸イオン : $\mathrm{Cr}_{2} \mathrm{O}_{7}^{2-}$ & $0.95 \sim 2.4 \mathrm{mg} / \mathrm{L}$ & \\
\hline $\mathrm{As}^{3+}$ & 亜七酸二水素イオン : $\mathrm{H}_{2} \mathrm{AsO}_{3}-$ & $0.0095 \sim 0.024 \mathrm{mg} / \mathrm{L}$ & \multirow{2}{*}{$4.5 \mathrm{mg} / \mathrm{L}$} \\
\hline $\mathrm{As}^{5+}$ & 七酸水素イオン: $\mathrm{HAsO}_{4}{ }^{2-}$ & $0.0095 \sim 0.024 \mathrm{mg} / \mathrm{L}$ & \\
\hline $\mathrm{Se}^{4+}$ & 悪セレン酸水素イオン: $\mathrm{HSeO}_{3}^{-}$ & $0.48 \sim 2.4 \mathrm{mg} / \mathrm{L}$ & \multirow{2}{*}{$4.5 \mathrm{mg} / \mathrm{L}$} \\
\hline $\mathrm{Se}^{6+}$ & セレン酸イオン： $\mathrm{SeO}_{4}{ }^{2-}$ & 急性毒性影響なし & \\
\hline
\end{tabular}
of heavy metals on the luminous bacteria

*発光バクテリア溶液 $1 \mathrm{~mL}$ に対し検液 $50 \mu \mathrm{L}$ であるので、実際の測定試料中の重金属 等の濃度は表 3 で示されている值の 21 分の 1 の值となる。

${ }^{* *} \mathrm{CN}$ については急性毒性影響ではなく、発光バクテリアに対して活性化影響を示す。

\section{4. 解析及び考察}

\section{1 重金属等の急性毒性影響に関する定量化}

発光バクテリアを用いた急性毒性試験におけ る曝露時間としては, Microtox ${ }^{\circledR}$ では15分, ISO 11348では, 5 分, 15分, 30分の3つが推奨されて いる。図 $2 \sim 5$ に示した本試験結果を見る限り, 曝露時間 5 分及び 15 分では $S$ の值が急速に減少 している途中にあるものが多く, 時間的な測定誤 差の影響が大きいと考えられる。また, 大部分の データは曝露時間30分と60分で $S$ の值に大きな差 異はないように見えるが, $\mathrm{Cd} や \mathrm{Cr}^{6+}, \mathrm{As}^{3+}, \mathrm{Se}^{4+}$ では曝露時間は30分では十分とは言えず, 60分の デー夕を用いる方が望ましいように思われる。本 研究の本質的な目的は, 土䁃污染の評価を行うた めの信頼性の高いデー夕の取得であることから, 本研究では, 曝露時間60分での $S$ の值を用いて, 各重金属等による急性毒性影響について解析及び 考察を行うこととした。なお，前述したように， $\mathrm{CN}, \mathrm{F}, \mathrm{Se}^{6+}$ については, 発光バクテリアに対し て急性毒性を示さなかったため, また，Bについ ては, 定量化に必要なデータの不足のため, 定量 化に関する検討を行わなかった。

\section{(1) $\mathrm{Cd}, \mathrm{Pb}, \mathrm{Hg}, \mathrm{Se}^{4+}$ の急性毒性に関する定量 化}

$\mathrm{Cd}, \mathrm{Pb}, \mathrm{Hg}, \mathrm{Se}^{4+}$ に関する各試験で得られた曝 露時間 60 分における発光バクテリアの相対発光強 度比の值 $S_{\mathrm{t}(60)}$ を, 発光強度測定試料中の各重金属 等の濃度 $C^{*}[\mathrm{mg} / \mathrm{L}]$ に対して片対数プロットし たものを図6（a）〜（d）にそれぞれ示す。いず れの図においても, ある濃度範囲において $S_{\mathrm{t}(60)}$ と $C^{*}$ の対数值の間に直線関係が認められる（各図 において,ひとつの近似曲線上にプロットされる と思われるデータを○で示した）。この近似曲線 は，近似式（5）として表わされる。

$$
S_{\mathrm{t}(60)}=\alpha-\beta \log C^{*}
$$

ここで， $\alpha$ 及び $\beta$ は式（5）のパラメータ值である。 本試験で得られたデータの中で近似式（5）に適 合できると思われる各重金属等の濃度範囲と, こ れら試験データの近似式（5）への適用によって 得られたパラメータ $\alpha, \beta$ の值及び相関係数 $R$ を表 

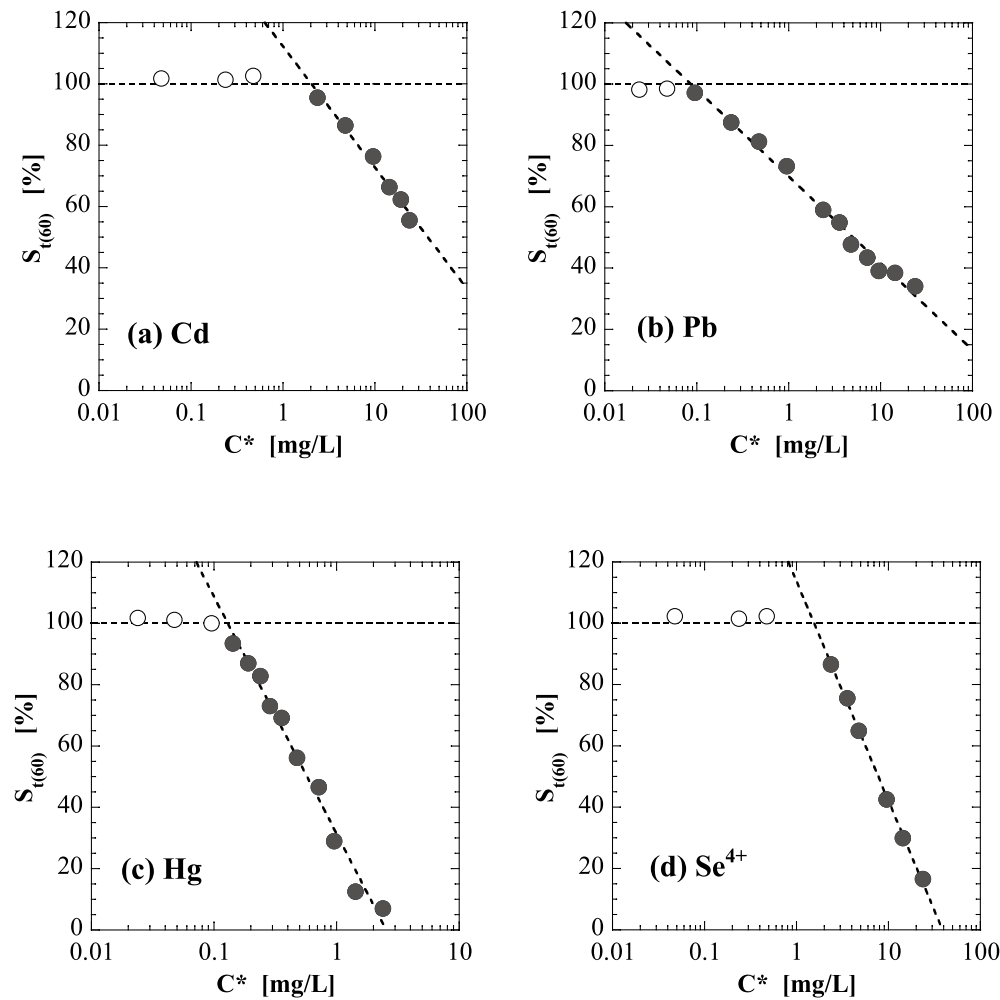

図 6 重金属濃度に対する反応時間 60 分での相対発光強度比の片対数プ ロット : (a) Cd, (b) Pb, (c) Hg, (d) $\mathrm{Se}^{4+}$

Fig. 6 Plot of relative luminescence intensity ratio of luminous bacteria against logarithm of heavy metals concentration: (a) $\mathrm{Cd}$, (b) $\mathrm{Pb}$, (c) $\mathrm{Hg}$ and $(\mathrm{d}) \mathrm{Se}^{4+}$

5 に記載している。このパラメータ $\alpha$ 及び $\beta$ の值を 用いれば, 実測した $S_{\mathrm{t}(60)}$ の值から污染物質の濃度 を求めることが可能である。

\section{（２）六価クロム $\mathrm{Cr}^{6+}$ の急性毒性に関する定量化}

クロム酸イオン及び二クロム酸イオンに関する 各試験で得られた曝露時間 60 分における発光バ クテリアの相対発光強度比の值 $S_{\mathrm{t}(60)}$ を, 発光強度 測定試料中のクロム濃度 $C^{\star}[\mathrm{mg} / \mathrm{L}]$ に対して片 対数プロットしたものを図 7 (a) 及び（b）にそ れぞれ示す。両図ともに, ある濃度範囲において $S_{\mathrm{t}(60)}$ と $C^{\star}$ の対数值の間に良好な直線関係が認め られる。近似式（5）の適用によって得られたパ ラメータ $\alpha, \beta$ 值及び相関係数 $R$ を表 5 に記載し ている。相関係数は両者ともに 0.99 以上と良好で ある。また, パラメータ $\alpha$ 及び $\beta$ ともにクロム酸イ オンの方が二クロム酸イオンの值よりも大きい。

\section{（3）砒素As の急性毒性に関する定量化}

$\mathrm{As}^{3+}$ 及び $\mathrm{As}^{5+}$ に関する各試験で得られた曝露 時間60分における発光バクテリアの相対発光強 度比の值 $S_{\mathrm{t}(60)}$, 発光強度測定試料中の砒素濃 度 $C^{\star}[\mathrm{mg} / \mathrm{L}]$ に対して片対数プロットしたもの を図 8 (a) 及び（b）にそれぞれ示す。また，近 似式（5）から得られたパラメータ $\alpha, \beta$ の值及び 相関係数 $R$ を表 5 に記載している。得られたパラ メー夕 $\alpha$ 及び $\beta$ の值を比較すると, $\mathrm{As}^{3+}$ と $\mathrm{As}^{5+}$ でほ

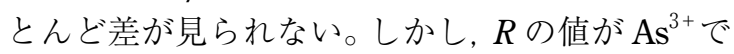

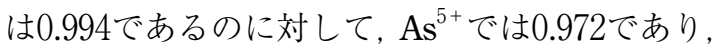
かなり低くなっている。これは, 本試験では検液 の $\mathrm{pH}$ を中性付近に調整しているが, 前節3.3でも 述べたように, 七酸の第二酸解離定数 $\mathrm{pKa}_{2}$ が6.94 という中性付近であるため, わずかな $\mathrm{pH}$ の違い によっても溶液中のヒ酸二水素イオン $\mathrm{H}_{2} \mathrm{AsO}_{4}{ }^{-}$ 

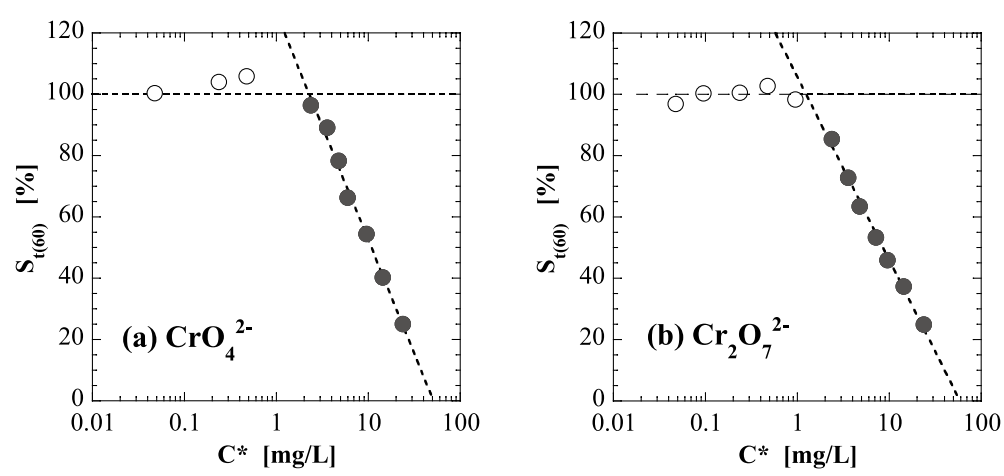

図 7 六価クロム濃度に対する反応時間 60 分での相対発光強度比の片対 数プロット : (a) $\mathrm{CrO}_{4}{ }^{2-}$ and (b) $\mathrm{Cr}_{2} \mathrm{O}_{7}{ }^{2-}$

Fig. 7 Plot of relative luminescence intensity ratio of luminous bacteria against logarithm of hexavalent chromium concentration: (a) $\mathrm{CrO}_{4}{ }^{2-}$ and (b) $\mathrm{Cr}_{2} \mathrm{O}_{7}{ }^{2-}$
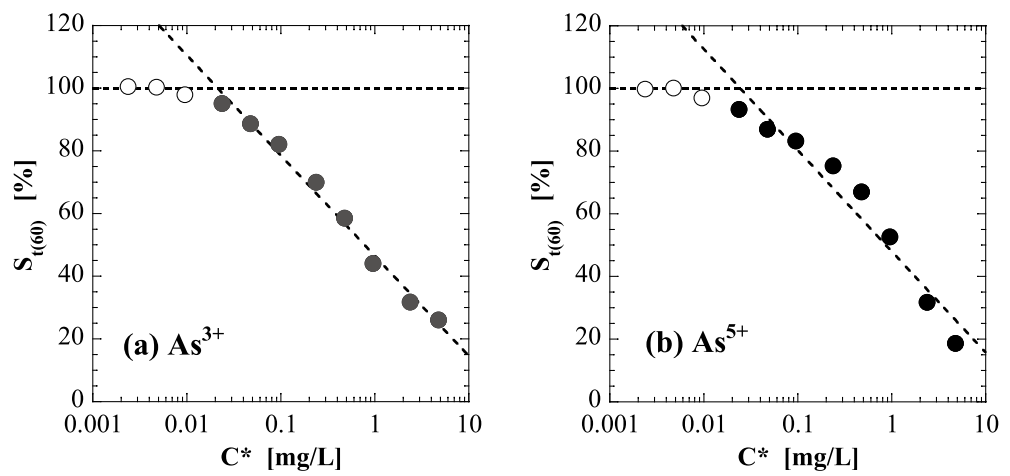

図8 砒素濃度に対する反応時間 60 分での相対発光強度比の片対数プ ロット : (a) $\mathrm{As}^{3+}$ and (b) $\mathrm{As}^{5+}$

Fig. 8 Plot of relative luminescence intensity ratio of luminous bacteria against logarithm of arsenic concentration: (a) $\mathrm{As}^{3+}$ and (b) $\mathrm{As}^{5+}$

とヒ酸水素イオン $\mathrm{HAsO}_{4}{ }^{2-}$ の割合が変化し, この 溶存形態の違いが発光バクテリアの発光強度に影 響を及ぼした可能性がある。本研究では発光強度 測定試料の実際の $\mathrm{pH}$ は測定していないため, 実 際の測定試料中の $\mathrm{H}_{2} \mathrm{AsO}_{4}{ }^{-}$と $\mathrm{HAsO}_{4}{ }^{2-}$ の割合を 求めることはできないので, 両者を区別せずに, $\mathrm{As}^{5+}$ の急性毒性を総括的に反映しているものとし て取り扱うこととする。

\section{2 重金属等の急性毒性影響の大きさの比較 （1）暴露時間60分を基準とした比較}

表 5 のパラメー夕值と近似式（5）を用いて, $S_{\mathrm{t}(60)}$ の值が100,50及び0\%になるときの各重金 属等の濃度 $C^{\star}{ }_{\mathrm{S}(100)}, C^{\star}{ }_{\mathrm{S}(50)}$ 及び $C^{\star}{ }_{\mathrm{S}(0)}[\mathrm{mg} / \mathrm{L}]$ を 求め, 得られたそれらの值を表 6 に記載した。

表 6 に記載されている $C^{\star}{ }_{\mathrm{S}(100)}$ は, 仮想的なもので はあるが, 発光バクテリアに急性毒性影響を及ぼ す各重金属等の間值であり, 本急性毒性試験での 検出限界濃度の目安にもなる。なお, $C^{\star}{ }_{\mathrm{s}(100)}$ を基 準とした検出性の高さは下記の順となる。 


$$
\begin{aligned}
\mathrm{As}^{3+}, \mathrm{As}^{5+}>\mathrm{Pb}^{2+}>\mathrm{Hg}^{2+}>\mathrm{Cr}^{6+}\left(\text { as }_{2} \mathrm{Cr}_{7}{ }^{2-}\right) \\
>\mathrm{Se}^{4+}>\mathrm{Cd}^{2+}>\mathrm{Cr}^{6+}\left(\text { as }_{\left.\mathrm{CrO}_{4}{ }^{2-}\right)}\right.
\end{aligned}
$$

上記は前項 3.5（2）に示した実際の試験結果 に基づく検出性の高さの順とはやや異なる部分も あるが, 各重金属等の $C^{\star}{ }_{\mathrm{S}(100)}$ の值自体は, 表 4 に 記載されている各閾值の濃度範囲にほぼ含まれ ている。したがって, 污染サイトのスクリーニン グを行う際の指標として表 6 に記載されている $C^{\star}{ }_{\mathrm{S}(100)}$ の值を用いることは妥当であると考えられ る。なお, $\mathrm{As}^{3+}$ と $\mathrm{As}^{5+}$ の $C^{\star}{ }_{\mathrm{s}(100)}$ の間にはほとんど 差異は無かった。

一方, 表 6 に記載している $C^{*}{ }_{\mathrm{s}(0)}$ もまた, 仮想 的なものではあるが, 試験生物群が全て死滅する 重金属等の濃度を意味している。 $C^{*} \mathrm{~s}(0)$ を基準と した急性毒性の強さは下記の順となる。

$$
\begin{aligned}
\mathrm{Hg}^{2+}>\mathrm{As}^{3+}>\mathrm{As}^{5+}> & \mathrm{Se}^{4+}>\mathrm{Cr}^{6+}\left(\text { as } \mathrm{CrO}_{4}{ }^{2-}\right) \\
& >\mathrm{Cr}^{6+}\left(\text { as } \mathrm{Cr}_{2} \mathrm{O}_{7}{ }^{2-}\right)>\mathrm{Pb}^{2+}>\mathrm{Cd}^{2+}
\end{aligned}
$$

砒素については, $C^{*}{ }_{\mathrm{s}(100)}$ と同様に価数の違いによ る $C^{\star}{ }_{\mathrm{s}(0)}$ の違いはわずかであり, 六価クロムにつ いてもクロム酸塩と二クロム酸塩の $C^{*}{ }_{\mathrm{s}(0)}$ の值に はそれほど大きな差はなかった。

一般に急性毒性を評価する指標として, 試験生 物群の $50 \%$ に影響を与える試験物質の濃度を意味 する $\mathrm{EC}_{50}$ (Median effect concentration) や試験 生物群の $50 \%$ が死滅する試験物質の濃度を意味す

\section{表 5 式（5）のパラメータ値及び相関係数の値}

Table 5 Data on parameters and correlation coefficients in equation (5)

\begin{tabular}{|c|c|c|c|c|}
\hline \multirow{2}{*}{ 対象物質 } & 適用濃度範囲 & \multicolumn{3}{|c|}{$S_{\mathrm{t}(60)}=\alpha-\beta$} \\
\cline { 3 - 5 } & $C^{*}[\mathrm{mg} / \mathrm{L}]$ & $\alpha$ & $\beta$ & $R$ \\
\hline $\mathrm{Cd}^{2+}$ & $2.38 \sim 23.8$ & 112.26 & 39.51 & 0.992 \\
\hline $\mathrm{Pb}^{2+}$ & $0.095 \sim 23.8$ & 69.87 & 28.31 & 0.995 \\
\hline $\mathrm{Hg}^{2+}$ & $0.143 \sim 2.38$ & 31.40 & 77.36 & 0.992 \\
\hline $\mathrm{Se}^{4+}$ & $2.38 \sim 23.8$ & 113.76 & 71.60 & 0.999 \\
\hline $\begin{array}{c}\mathrm{Cr}^{6+} \\
\left(\mathrm{CrO}_{4}{ }^{2-}\right)\end{array}$ & $2.38 \sim 23.8$ & 126.59 & 74.08 & 0.996 \\
\hline $\begin{array}{c}\mathrm{Cr}^{6+} \\
\left(\mathrm{Cr}_{2} \mathrm{O}_{7}{ }^{2-}\right)\end{array}$ & $2.38 \sim 23.8$ & 105.72 & 59.72 & 0.997 \\
\hline $\mathrm{As}^{3+}$ & $0.024 \sim 4.76$ & 46.53 & 32.01 & 0.994 \\
\hline $\mathrm{As}^{5+}$ & $0.024 \sim 4.76$ & 47.99 & 32.29 & 0.972 \\
\hline
\end{tabular}

る $\mathrm{LC}_{50}$ (Median lethal concentration) が使用され ているが, 発光バクテリアの代謝による発光量が $50 \%$ 低下する試験物質の濃度を意味する本研究で 使用した $C^{\star}{ }_{\mathrm{S}(50)}$ 本質的にはそれらと同等の指標 となるものであり， $C^{\star}{ }_{\mathrm{S}(50)}$ を基準とした急性毒性 の強さは下記の順となる。

$$
\begin{aligned}
\mathrm{Hg}^{2+} & >\mathrm{As}^{3+}>\mathrm{As}^{5+}>\mathrm{Pb}^{2+}>\mathrm{Se}^{4+} \\
& >\mathrm{Cr}^{6+}\left(\text { as } \mathrm{Cr}_{2} \mathrm{O}_{7}^{2-}\right)>\mathrm{Cr}^{6+}\left(\text { as } \mathrm{CrO}_{4}{ }^{2-}\right)>\mathrm{Cd}^{2+}
\end{aligned}
$$

\section{（2）暴露時間15分を基準とした比較}

土壌污染評価を想定しない有害物質の急性毒性 影響の強さのみに着目した水質分野で行われてい る急性毒性試験では, 暴露時間15分における急性 毒性值を指標とする場合が比較的多い。そこで, 本研究でも曝露時間15分におけるデー夕を用い た解析を行った。まず, $\mathrm{Cd}, \mathrm{Pb}, \mathrm{Hg}, \mathrm{Se}^{4+}, \mathrm{Cr}^{6+}$ $\left(\mathrm{CrO}_{4}{ }^{2-}\right.$ 及び $\left.\mathrm{Cr}_{2} \mathrm{O}_{7}{ }^{2-}\right), \mathrm{As}\left(\mathrm{As}^{3+}\right.$ 及び $\left.\mathrm{As}^{5+}\right)$ に関 する各試験で得られた曝露時間15分における発光 バクテリアの相対発光強度比の值 $S_{\mathrm{t}(15)}$ を, 発光強 度測定試料中の各重金属等の濃度 $C^{*}[\mathrm{mg} / \mathrm{L}] に$ 対して片対数プロットしたものを図 9 (a) 〜 (h) にそれぞれ示す。いずれの図においても, 曝露時 間60分のデー夕と同様に, ある濃度範囲におい

\begin{tabular}{|c|c|c|c|}
\hline \multirow{2}{*}{ 対象物質 } & $C^{*}{ }_{\mathrm{s}(100)}$ & $C^{*} \mathrm{~s}_{\mathrm{S}(50)}$ & $C^{*}{ }_{\mathrm{s}(0)}$ \\
\hline & \multicolumn{3}{|c|}{$[\mathrm{mg} / \mathrm{L}]$} \\
\hline $\mathrm{Cd}^{2+}$ & 2.04 & 37.7 & 694 \\
\hline $\mathrm{Pb}^{2+}$ & 0.09 & 5.03 & 294 \\
\hline $\mathrm{Hg}^{2+}$ & 0.13 & 0.57 & 2.55 \\
\hline $\mathrm{Se}^{4+}$ & 1.56 & 7.77 & 38.8 \\
\hline $\begin{array}{c}\mathrm{Cr}^{6+} \\
\left(\mathrm{CrO}_{4}{ }^{2-}\right)\end{array}$ & 2.29 & 10.8 & 51.2 \\
\hline $\begin{array}{c}\mathrm{Cr}^{6+} \\
\left(\mathrm{Cr}_{2} \mathrm{O}_{7}^{2-}\right)\end{array}$ & 1.25 & 8.57 & 58.9 \\
\hline $\mathrm{As}^{3+}$ & 0.02 & 0.78 & 28.4 \\
\hline $\mathrm{As}^{5+}$ & 0.02 & 0.87 & 30.6 \\
\hline
\end{tabular}
て $S_{\mathrm{t}(15)}$ と $C^{*}$ の対数值の間に直線関係が認められ

表 6 暴露時間 60 分における $C^{\star}{ }_{\mathrm{s}(100)}, C^{\star}{ }_{\mathrm{s}(50)}$, $C^{\star}{ }_{\mathrm{s}(0)}$ の計算値

Table 6 Calculated values of $C^{*}{ }_{s(100)}, C^{*}{ }_{s(50)}$ and $C^{*}{ }^{*(0)}$ in 60 minutes of exposure time 
る。この近似曲線は, 近似式（6）として表わされ る。

$$
S_{\mathrm{t}(15)}=\gamma-\delta \log C^{\star}
$$
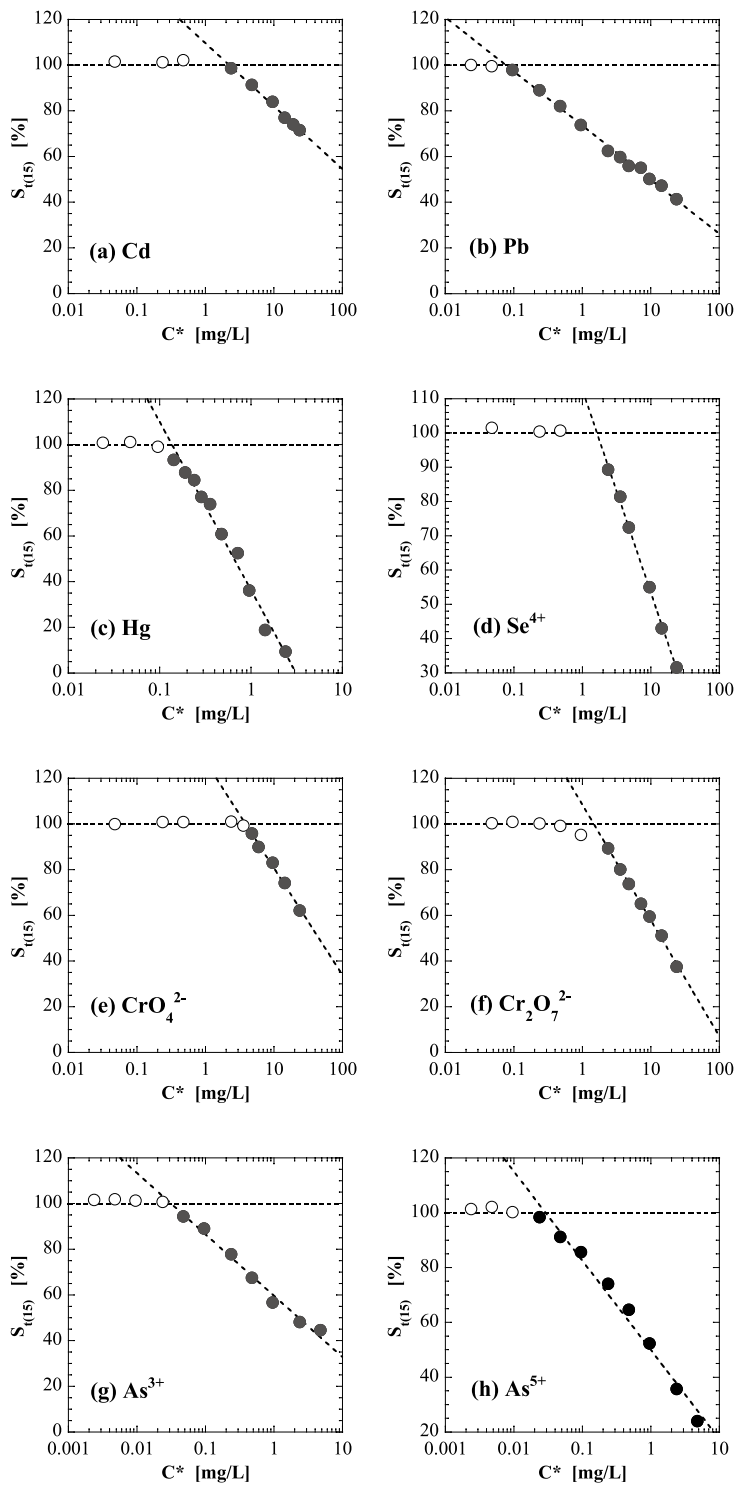

図 9 重金属濃度に対する暴露時間 15 分での相対 発光強度比の片対数プロット: (a) Cd, (b) $\mathrm{Pb}$, (c) $\mathrm{Hg}$, (d) $\mathrm{Se}^{4+}$, (e) $\mathrm{CrO}_{4}{ }^{2-}$, (f) $\mathrm{Cr}_{2} \mathrm{O}_{7}{ }^{2-}$, (g) $\mathrm{As}^{3+}$, (h) $\mathrm{As}^{5+}$

Fig. 9 Plot of relative luminescence intensity ratio in 15 minutes of exposure time against logarithm of heavy metals concentration: (a) $\mathrm{Cd}$, (b) $\mathrm{Pb}$, (c) $\mathrm{Hg}$, (d) $\mathrm{Se}^{4+}$, (e) $\mathrm{CrO}_{4}{ }^{2-}$, (f) $\mathrm{Cr}_{2} \mathrm{O}_{7}{ }^{2-},(\mathrm{g}) \mathrm{As}^{3+}$ and (h) $\mathrm{As}^{5+}$

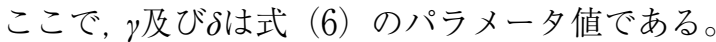
本試験で得られたデータの中で近似式（6）に適 合できると思われる各重金属等の濃度範囲と, こ れら試験データの近似式（6）への適用によって 得られたパラメータ $\gamma, \delta$ の值及び相関係数 $R$ を表 7 に記載する。また, 表 7 のパラメータ值と近似 式（6）を用いて， $S_{\mathrm{t}(15)}$ の值が100，50及び $0 \%$ に なるときの各重金属等の濃度 $C^{\star}{ }_{\mathrm{s}(100),} C^{\star}{ }_{\mathrm{s}(50)}$ 及び $C^{\star}{ }_{\mathrm{s}(0)}[\mathrm{mg} / \mathrm{L}]$ を求め, 得られたそれらの值を表 8 に記載した。さらに, $C^{\star}{ }_{\mathrm{s}(100),} C^{\star}{ }_{\mathrm{s}(50)}$ 及び $C^{\star}{ }_{\mathrm{s}(0)}$

表 7 式（6）のパラメータ值及び相関係数の値

Table 7 Data on parameters and correlation coefficients in equation (6)

\begin{tabular}{|c|c|c|c|c|}
\hline \multirow{2}{*}{ 対象物質 } & 適用濃度範囲 & \multicolumn{3}{|c|}{$S_{\mathrm{t}(15)}=\gamma-\delta$} \\
\cline { 3 - 5 } & $C^{*}[\mathrm{mg} / \mathrm{L}]$ & $\gamma$ & $\delta$ & $R$ \\
\hline $\mathrm{Cd}^{2+}$ & $2.38 \sim 23.8$ & 109.63 & 27.56 & 0.998 \\
\hline $\mathrm{Pb}^{2+}$ & $0.095 \sim 23.8$ & 73.60 & 23.69 & 0.998 \\
\hline $\mathrm{Hg}^{2+}$ & $0.143 \sim 2.38$ & 36.34 & 73.64 & 0.992 \\
\hline $\mathrm{Se}^{4+}$ & $2.38 \sim 23.8$ & 112.764 & 59.22 & 0.999 \\
\hline $\begin{array}{c}\mathrm{Cr}^{6+} \\
\left(\mathrm{CrO}_{4}{ }^{2-}\right)\end{array}$ & $4.76 \sim 23.8$ & 127.547 & 46.81 & 0.997 \\
\hline $\begin{array}{c}\mathrm{Cr}^{6+} \\
\left(\mathrm{Cr}_{2} \mathrm{O}_{7}{ }^{2-}\right)\end{array}$ & $2.38 \sim 23.8$ & 108.48 & 50.68 & 0.999 \\
\hline $\mathrm{As}^{3+}$ & $0.024 \sim 4.76$ & 59.66 & 26.87 & 0.993 \\
\hline $\mathrm{As}^{5+}$ & $0.024 \sim 4.76$ & 49.96 & 32.56 & 0.992 \\
\hline
\end{tabular}

表 8 暴露時間 15 分における $C^{*}{ }_{\mathrm{S}(100)}, C^{\star}{ }_{\mathrm{S}(50)}$, $C^{*}{ }^{*(0)}$ の計算値

Table 8 Calculated values of $C^{*}{ }_{s(100)}, C^{\star}{ }_{s(50)}$ and $C^{*}{ }_{(0)}$ in 15 minutes of exposure time

\begin{tabular}{|c|c|c|c|}
\hline \multirow{2}{*}{ 対象物質 } & $C^{*}{ }^{\mathrm{S}(100)}$ & \multicolumn{1}{|c|}{$C^{*} \mathrm{~s}(50)$} & $C^{*} \mathrm{~s}(0)$ \\
\cline { 2 - 4 } & \multicolumn{3}{|c|}{$[\mathrm{mg} / \mathrm{L}]$} \\
\hline $\mathrm{Cd}^{2+}$ & 2.24 & 145 & 9509 \\
\hline $\mathrm{Pb}^{2+}$ & 0.08 & 9.92 & 1280 \\
\hline $\mathrm{Hg}^{2+}$ & 0.14 & 0.65 & 3.12 \\
\hline $\mathrm{Se}^{4+}$ & 1.63 & 11.4 & 79.8 \\
\hline $\begin{array}{c}\mathrm{Cr}^{6+} \\
\left(\mathrm{CrO}_{4}{ }^{2-}\right)\end{array}$ & 3.86 & 45.2 & 529 \\
\hline $\begin{array}{c}\mathrm{Cr}^{6+} \\
\left(\mathrm{Cr}_{2} \mathrm{O}_{7}{ }^{2+}\right)\end{array}$ & 1.47 & 14.3 & 138 \\
\hline $\mathrm{As}^{3+}$ & 0.03 & 2.29 & 166 \\
\hline $\mathrm{As}^{5+}$ & 0.03 & 1.00 & 34.2 \\
\hline
\end{tabular}


を基準とした重金属等の急性毒性の強さの大小 関係を表 9 に示す。また，比較を容易にするため に, 暴露時間60についても表 9 に併記した。発光 バクテリアに及ぼす重金属等の急性毒性の強さ の大小関係は $C^{\star}{ }_{\mathrm{s}(100)}$ については暴露時間15分と 60分で差異は見られない。また， $C^{*}{ }_{\mathrm{S}(50)}$ について は, 暴露時間15分と60分で $\mathrm{As}^{5+}$ と $\mathrm{As}^{3+}$ の大小関 係が入れ替わっているが, $\mathrm{As}^{5+}$ と $\mathrm{As}^{3+}$ に関する急 性毒性值の值自体に大きな差はない（表 6 及び 8 参照)。一方, $C^{*}{ }_{\mathrm{s}(0)}$ については, 急性毒性は $\mathrm{Hg}$ が 最も強く, $\mathrm{Pb}$ 及び $\mathrm{Cd}$ が弱いことは一致している が, その他の重金属等の急性毒性の強さの大小関 係についてはかなりの差異が見られる。

また, 暴露時間60分（表6) と15分（表 8 ）の 值を比較すると $C^{*} \mathrm{~s}(100)$ については大きな違い はないが, $C^{\star}{ }_{\mathrm{s}(50)}$ 及び $C^{\star}{ }_{\mathrm{s}(0)}[\mathrm{mg} / \mathrm{L}]$ については $\mathrm{Hg}^{2+}$ と $\mathrm{As}^{5+}$ を除く重金属等で大きな違いがある ことがわかる。以上の結果からも, バイオアッセ イによって有害物質の急性毒性の強さを判断する 場合, 暴露時間の設定が非常に重要であることは 明らかである。

\section{（3）文献値との比較}

他の研究者による既往の研究において, 本研究 と同様にVibrio fischeri を用いたバイオアッセイ によって調べられた重金属等の急性毒性值が報告 されている。報告されている $\mathrm{EC}_{50}$ の值のいくつか の例を表10に示す。なお，それぞれの研究におけ る暴露時間は Codina et al. (1994), McCloskey et al. (1996), Mowat and Bundy（2002）では15分, McFeters et al. (1983) では5 分, Gallert (1999) は 6 時間, Heseih et al. (2004) では22時間となっ ている。表10の暴露時間15分の $\mathrm{EC}_{50}$ (本研究では $C^{\star}{ }_{\mathrm{S}(50)}$ が相当) の文献值の比較から研究者によっ
て報告している值が大きく異なっていることがわ かる。このように, バイオアッセイにおいては報 告される值に大きな隔たりがあることがしばしば 見受けられる。これは発光バクテリアの培養方法 や薬品の調製方法, 試験手順等に関してそれぞれ の論文に記述されていない部分で何らかの違いが あることが予想され，それらの違いが要因となっ て試験結果に違いが生じているものと推測され る。

一般的には暴露時間が長いものほど $\mathrm{EC}_{50}$ の值 は小さくなるはずであるが, 表 9 に載せた暴露時 間 5 分〜22時間の文献值の比較では, 必ずしも そのような結果にはなっていない。このことから も, 異なる研究者間のデータの相互利用の難し さが浮き彫りになっている。なお, 本研究では, 表 6 と表 8 の比較から明らかなように, $\mathrm{Pb}^{2+}$ の $C^{*}{ }_{\mathrm{S}(100)}$ を除けば暴露時間60分での值（表 6 ）の方 が暴露時間15分での值（表 8) よりも小さくなっ ており, 確立された一定条件下で行われた試験か ら得られた值ならば，矛盾せずに相互利用できる と考えられる。

\section{3 第二種特定有害物質に関する污染評価手 法としての適合性}

本研究によって得られた急性毒性試験結果及び 解析結果から, 第二種特定有害物質に指定されて いる重金属等のうち, シアン, ふっ素の 2 種につ いては発光バクテリアに対して急性毒性影響を及 ぼさないため, 本手法による土畩污染評価を行う ことができないが, カドミウム, 鉛, 水銀, 六価 クロム, 砒素, セレンの 6 種については本手法に よって土壤污染評価を簡便かつ効果的に行える可 能性が見出された。なお,ほう素については, 有

表 9 ビブリオフィッシェリに関する重金属等の急性毒性の強さの比較

Table 9 Comparison of acute toxicity strength of heavy metals for Vibrio fischeri

\begin{tabular}{|c|c|c|}
\hline 急性毒性値 & 暴露時間 & 重金属等の急性毒性の強さの比較 \\
\hline \multirow{2}{*}{$C^{*} \mathrm{~s}(100)$} & $15 \mathrm{~min}$ & $\mathrm{As}^{3+}, \mathrm{As}^{5+}>\mathrm{Pb}^{2+}>\mathrm{Hg}^{2+}>\mathrm{Cr}^{6+}\left(\right.$ as $\left.\mathrm{Cr}_{2} \mathrm{O}_{7}{ }^{2-}\right)>\mathrm{Se}^{4+}>\mathrm{Cd}^{2+}>\mathrm{Cr}^{6+}\left(\right.$ as $\left.\mathrm{CrO}_{4}{ }^{2-}\right)$ \\
\hline & $60 \mathrm{~min}$ & $\mathrm{As}^{3+}, \mathrm{As}^{5+}>\mathrm{Pb}^{2+}>\mathrm{Hg}^{2+}>\mathrm{Cr}^{6+}\left(\right.$ as $\left.\mathrm{Cr}_{2} \mathrm{O}_{7}{ }^{2-}\right)>\mathrm{Se}^{4+}>\mathrm{Cd}^{2+}>\mathrm{Cr}^{6+}\left(\right.$ as $\left.\mathrm{CrO}_{4}{ }^{2-}\right)$ \\
\hline \multirow{2}{*}{$C^{*} \mathrm{~s}(50)$} & $15 \mathrm{~min}$ & $\mathrm{Hg}^{2+}>\mathrm{As}^{5+}>\mathrm{As}^{3+}>\mathrm{Pb}^{2+}>\mathrm{Se}^{4+}>\mathrm{Cr}^{6+}\left(\right.$ as $\left.\mathrm{Cr}_{2} \mathrm{O}_{7}{ }^{2-}\right)>\mathrm{Cr}^{6+}\left(\right.$ as $\left.\mathrm{CrO}_{4}{ }^{2-}\right)>\mathrm{Cd}^{2+}$ \\
\hline & $60 \mathrm{~min}$ & $\mathrm{Hg}^{2+}>\mathrm{As}^{3+}>\mathrm{As}^{5+}>\mathrm{Pb}^{2+}>\mathrm{Se}^{4+}>\mathrm{Cr}^{6+}\left(\right.$ as $\left.\mathrm{Cr}_{2} \mathrm{O}_{7}{ }^{2-}\right)>\mathrm{Cr}^{6+}\left(\right.$ as $\left.\mathrm{CrO}_{4}{ }^{2-}\right)>\mathrm{Cd}^{2+}$ \\
\hline \multirow{2}{*}{$C^{*} \mathrm{~s}(0)$} & $15 \mathrm{~min}$ & $\mathrm{Hg}^{2+}>\mathrm{As}^{5+}>\mathrm{Se}^{4+}>\mathrm{Cr}^{6+}\left(\right.$ as $\left.\mathrm{Cr}_{2} \mathrm{O}_{7}{ }^{2-}\right)>\mathrm{As}^{3+}>\mathrm{Cr}^{6+}\left(\right.$ as $\left.\mathrm{CrO}_{4}{ }^{2-}\right)>\mathrm{Pb}^{2+}>\mathrm{Cd}^{2+}$ \\
\hline & $60 \mathrm{~min}$ & $\mathrm{Hg}^{2+}>\mathrm{As}^{3+}>\mathrm{As}^{5+}>\mathrm{Se}^{4+}>\mathrm{Cr}^{6+}\left(\right.$ as $\left.\mathrm{CrO}_{4}{ }^{2-}\right)>\mathrm{Cr}^{6+}\left(\right.$ as $\left.\mathrm{Cr}_{2} \mathrm{O}_{7}{ }^{2-}\right)>\mathrm{Pb}^{2+}>\mathrm{Cd}^{2+}$ \\
\hline
\end{tabular}


表 10

ビブリオフィッシェリに関する重金属等の急性毒性值 $\mathrm{EC}_{50}$ に関す る文献値

Table 10 Literature values for $\mathrm{EC}_{50}$ of heavy metals for Vibrio fischeri

\begin{tabular}{|c|c|c|c|c|c|c|c|}
\hline 文献 & This work & $\begin{array}{c}\text { Codina } \\
\text { et al. } \\
(1994)\end{array}$ & $\begin{array}{c}\text { McCloskey } \\
\text { et al. } \\
(1996)\end{array}$ & $\begin{array}{c}\text { Mowat and } \\
\text { Bundy } \\
(2002)\end{array}$ & $\begin{array}{c}\text { McFeters } \\
\text { et al. } \\
(1983) \text { it 2) }\end{array}$ & $\begin{array}{c}\text { Gellert } \\
(1999)\end{array}$ & $\begin{array}{c}\text { Hseih } \\
\text { et al. } \\
(2004)\end{array}$ \\
\hline 暴露時間 & $15 \mathrm{~min}$ & $15 \mathrm{~min}$ & $15 \mathrm{~min}$ & $15 \mathrm{~min}$ & $5 \mathrm{~min}$ & $6 \mathrm{~h}$ & $22 \mathrm{~h}$ \\
\hline 急性毒性值 & $\mathrm{EC}_{50}$ & $\mathrm{EC}_{50}$ & $\mathrm{EC}_{50}$ & $\mathrm{EC}_{50}$ & $\mathrm{EC}_{50}$ & $\mathrm{EC}_{50}$ & $\mathrm{EC}_{50}$ \\
\hline 嶩度単位 & $\mathrm{mg} / \mathrm{L}$ & $\mathrm{mg} / \mathrm{L}$ & $\mathrm{mg} / \mathrm{L}$ i 1$)$ & $\mathrm{mg} / \mathrm{L}$ & $\mathrm{mg} / \mathrm{L}$ & $\mathrm{mg} / \mathrm{L}$ & $\mathrm{mg} / \mathrm{L}$ \\
\hline $\mathrm{Cd}^{2+}$ & 146 & 34.7 & 3.04 & 59.3 & 255 & 28.9 & 504 \\
\hline $\mathrm{Pb}^{2+}$ & 9.92 & & 0.24 & 0.427 & & 272 & 669 \\
\hline $\mathrm{Hg}^{2+}$ & 0.65 & 0.2 & 0.18 & 0.103 & 0.04 & 0.12 & 33.8 \\
\hline $\mathrm{Se}^{4+}$ & 11.42 & & & & & & 114 \\
\hline $\begin{array}{c}\mathrm{Cr}^{6+} \\
\left(\mathrm{CrO}_{4}{ }^{2-}\right)\end{array}$ & 45.2 & & & & 64.7 & & \\
\hline $\mathrm{Cr}^{6+}$ & 14.3 & 339.6 & & 66.4 & & 15.9 & 12.4 \\
$\left(\mathrm{Cr}_{2} \mathrm{O}_{7}{ }^{2-}\right)$ & 2.29 & & & 8.68 & & & 821 \\
\hline $\mathrm{As}^{3+}$ & 2.00 & & & 22.1 & & & \\
\hline $\mathrm{As}^{5+}$ & 1.00 & & & & & \\
\hline
\end{tabular}

注 1) McCloskey et al. (1996)での濃度単位は $\mu \mathrm{M} / \mathrm{L}$ であったので、 $\mathrm{mg} / \mathrm{L}$ に換算した值を 記載した。

注 2) McFeters et al. (1983)では化合物の濃度であったので、元素濃度に換算した值を記 載した。

効な急性毒性試験データの不足のため, 定量性に ついては不明であるが, 表 4 に記載している值か ら污染サイトのスクリーニング手法としては利用 できる可能性がある。また, 本手法では, 六価セ レン $\mathrm{Se}^{6+}$ についても検出することができないが, 土壤環境下が還元雲囲気であることを考慮すれ

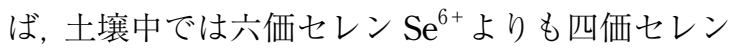
$\mathrm{Se}^{4+}$ の方が存在形態としては優勢であると考えら えるため, 本手法によって Seについても污染評 価を行うことが可能であると考えらえる。一方, 六価クロム及び砒素については, 図 3 及び図 4 に 示されているように, 溶存形態や価数の違いに よって発光バクテリアに及ぼす急性毒性影響に違 いがあることは明白であるが, 急性毒性評価の指 標として $S_{\mathrm{t}(60)}$ を採用することによって, 表 6 を見 てもわかるように, $C^{\star}{ }_{\mathrm{s}(100),} C^{\star}{ }_{\mathrm{s}(50)}$ 及び $C^{*}{ }_{\mathrm{s}(0)}$ のい ずれを比較しても, 溶存形態や価数の違いによる 差異は大きいものではなく, むしろ $\mathrm{As}^{3+}$ と $\mathrm{As}^{5+}$ についてはほとんど差異が認められなかった（た だし， $\mathrm{As}^{5+}$ の相関係数が低いことは考慮すべきか もしれない)。これらの結果から, 六価クロム及び 砒素についても， $S_{\mathrm{t}(60)}$ を用いることによって溶存 形態や価数を気にせずに土潩污染評価を行うこと
が可能であると考えられる。

以上から, 本手法は, 第二種特定有害物質に指 定されている重金属等のうち, 鉛 $\mathrm{Pb}$, 水銀 $\mathrm{Hg}$, 六価クロム $\mathrm{Cr}^{6+}$, 砒素 $\mathrm{As}$, セレン $\mathrm{Se}$ の 5 種に対 して, 土壤含有量基準值を指標とした土壤污染評 価を行うことが十分に可能であると考えられる。 また, カドミウム Cdについても土壤含有量基準 值に極めて近い濃度範囲まで定量性が確認されて いるため, 本手法はカドミウム污染土壤の簡易評 価手法としても役立てることができると考えられ る。

\section{5.土壤污染サイトへの適用方法}

本手法では污染物質の種類の判別を行うことは 原理的に不可能であるため, 土地の利用履歴が既 知であり, 検出される可能性がある污染物質が明 らかである場合に最も有効であると考えられる が，污染物質が未知である場合にも，污染物質が 発光バクテリアに対して急性毒性影響を示す物質 であるならば適用可能である。本手法の基本的な 適用方法としては, 大きくは, (a) 土壌污染サイ トのスクリーニングと（b）土壤污染浄化モニタ 
リングの 2 つが考えられる。従来の ICP 等精密分 析機器を用いた分析と比較してそれぞれ以下の大 きなメリットがある。

（a）土壤污染サイトのスクリーニングにおけるメ リット

(1) 土壤污染の疑いのあるサイトにおいて, 当該 手法による急性毒性試験を実施することに よって, オンサイトで污染の可能性の有無を 知ることができる。

(2) 土壤污染の疑いのあるサイトにおいて, 複数 の場所から採取した土畩試料を用いてそれぞ れ検液を作成し, 同時測定することによって その場で污染源をある程度絞り込むことがで きる。

（b）土壤污染浄化モニタリングにおけるメリッ 卜

(1) 污染浄化実施期間において本手法による急性 毒性試験を定期的に実施することによって污 染浄化状況をほぼオンタイム・オンサイトで 把握することができる。

(2) 公定法に準じた精密な分析は基本的には浄化 前と浄化完了時の計 2 回で済ますことができ るため, ICP 等による室内分析回数や分析費 用を大幅に削減できることが期待される。

以下に污染サイトで行うスクリーニングテスト の具体的な適用方法例を紹介する。

\section{1 一次スクリーニングテスト}

公定法に準ずる場合, 土壤試料と $1 \mathrm{~mol} / \mathrm{L}$ 塩酸 を重量体積比 $3 \%$ で混合（例えば30g：1 L) して 1 時間の振蕰を行った後, 孔径 $0.45 \mu \mathrm{m}$ のフィル ターでろ過し，抽出液を検液の原液として回収す る。回収した抽出液を所定量（例えば, $100 \mathrm{~mL}$ ) 分取して水酸化ナトリウム溶液で中和して $\mathrm{pH}$ が 中性付近になるように調整する。デー夕解析の際 に, この中和工程により容量増加した分について も希䣋率として濃度補正することを忘れてはなら ない。また, 中和過程で析出物が生じていないか 確認することも重要である。なお, 未中和の残り の抽出液は実験室に持ち帰り, ICP 等で定性及び
定量分析用の試料とする。一次スクリーニングテ ストでは, この中和した抽出水をそのまま検液と して, 本手法と同じ方法で発光バクテリアによる 急性毒性試験を行い, 污染物質の急性毒性影響の 有無を確認する。

一次スクリーニングテストでは, ブランク試料 として以下の 2 種類を用いる。

・第一ブランク試料：イオン交換水

・第二ブランク試料：抽出液として使用したもの と同じ $1 \mathrm{~mol} / \mathrm{L}$ 塩酸を水酸化ナトリウム溶液で 中和したもの。

さらに, この二つのブランク試料の他, 比較の ため試料無添加で発光バクテリア溶液のみの測定 も同時に行う。そのため, 本研究で使用した測定 用プレートに24個のセルがあるルミノメーター の場合, 一度の試験で判定できる土壤は最大で 5 つということになる。つまり，24個のセルに対し て, (1)試料無添加, (2)第一ブランク試料, (3)第二 ブランク試料, (4)検液 1, (5)検液 2, (6)検液 3, (7) 検液 4, 8検液 5 を各 3 セルずつ割り当てること になる。

通常(1), (2), (3)で測定される発光強度の変動は ほぼ同じ挙動を示すが，まれに(3)が(1)あるいは(2) と異なる挙動を示す場合がある。その場合, 相対 発光強度比の算出に使用するブランク值としては (3)の值を採用する。

\section{2 一次スクリーニングテストのアレンジ}

スクリーニング実施サイトにおいて, 污染物質 があることが明らかであるにも関わらず，一次ス クリーニングテストにおいて污染物質による急性 毒性影響が検知されなかった場合は, 発光バクテ リア溶液に添加する検液の量を増やして急性毒性 影響の有無を再確認する。また, 污染濃度が低い と予想されるとき，あるいは重量体積比 $3 \%$ では 急性毒性影響を検知できなかった場合には，検液 量を増やす以外にも, あらかじめ抽出工程で土壤 試料の割合を増やす, あるいは発光バクテリア溶 液中の発光バクテリア濃度を高くするなどの調 整を行う。なお, 発光バクテリア濃度を高くする 場合, ルミノメーターの検出上限を考慮し, オー バーレンジしないように調整しなければならな い。そのため, 例えば, 発光バクテリア濃度を通 
常の 2 倍にしたのなら, セルに分取する発光バク テリア溶液の量を通常の 2 分の 1 (つまり, $1 \mathrm{~mL}$

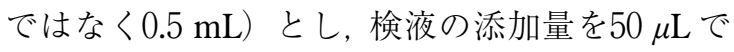
はなく550 $\mu \mathrm{L}$ に変更するなどすれば, 発光強度の 上限は通常の試験の場合と同じであるにも関わら ず，検出感度は実質的に通常の11倍にすることで きる。

なお, 現場で十分な時間が取れない場合は振と う時間を短縮してもよいが, 以降のモニタリング 測定等における連続性を持たせるために振とう時 間は一定の時間に固定するなど細かな配慮が必要 である。

\section{3 二次スクリーニングテスト}

発光バクテリアに対していずれかの検液に急性 毒性影響が確認された場合, 現場において十分な 時間が確保されるならば, 一次スクリーニングテ ストに続いて, 次の二次スクリーニングテストを 行うことが望ましい。

この二次スクリーニングテストでは, 一次スク リーニングテストにおいて急性毒性影響が最も強 かった試料を用いる。一次スクリーニングテスト で残った抽出液から所定量（例えば, $100 \mathrm{~mL}$ ) 分 取して一次スクリーニングテスト同様の手順で 中和し, 中和完了後の抽出液を原液として, 所定 の希釈率になるようにイオン交換水を加え希釈 率の $3 \sim 7$ つの異なる検液を作成する。希釈率は 一次スクリーニングテストで確認した急性毒性影 響の大きさを考慮して任意に決定する。例えば, 一次スクリーニングでの急性毒性影響が比較的大 きかった場合 $\left(S_{\mathrm{t}(60)}\right.$ が $20 \%$ 程度）には, 検液は無 希釈，2 倍希釈，5倍希釈，10倍希釈，20倍希釈， 50 倍希釈, 100倍希釈とし, 急性毒性影響が比較 的小さかった場合 $\left(S_{\mathrm{t}(60)}\right.$ が60\%程度) には, 検液 は無希釈, 1.2 倍希釈, 1.5倍希瀵, 2 倍希釈， 3 倍 希釈，5倍希釈，10倍希釈とすれば，それぞれブ ランク試料を足すと 8 種類となる。各 3 セルずつ 同じ試料の測定を行うので計24セルが必要であ るが, 本研究で使用しているルミノメーターは24 セル付プレートを採用しているので, 一連の測定 は 1 回の試験で済む。なお, 二次スクリーニング テストのブランク試料としては, 通常は章 5.1 で述べた第二ブランク試料を用いるが, 一次スク
リーニングテストにおいて第一ブランク試料と第 二ブランク試料の測定結果がほぼ同じだった場合 は第一ブランク試料, つまりイオン交換水を二次 スクリーニンテストのブランク試料としても良 w。

二次スクリーニングテストで得られた相対発光 強度比のデータと, 後日, ICP 等で得られた定量 分析值を組み合わせることによって污染サイトに 適合した検量線を作成することができる。また, この検量線と本試験で報告した表 5 のパラメータ 值を比較することによって主污染物質以外の副成 分の影響などその污染サイト固有の特徴を知るこ とができる。

\section{4 土壤污染浄化モニタリング}

最初に前述の一次及び二次スクリーニングテス トと同様の試験を実施し, 土潩污染サイトにおけ る急性毒性影響の大きさと污染物質濃度との相 関性を把握する。そして, 土壤污染浄化実施期間 において, 定期的に現場にて発光バクテリアによ る急性毒性試験を実施し, 急性毒性影響の大きさ の変動をモニタリングする。最終的に, 本手法に よって急性毒性影響がほぼ無くなったと判断され た段階,つまり污染物質が完全に浄化されたと推 測された段階で改めて土壤試料を実験室に持ち帰 り, 公定法に準じた分析を行い, 污染物質が浄化 されたことを確認する。

以上は本手法の土畩污染サイトへの基本的な適 用方法であるが, 各污染サイトの特性や試験目的 に応じて適切なアレンジを施すことが望ましい。

\section{6. まとめ}

土壤污染対策法の第二種特定有害物質に指定さ れている重金属等 9 種について発光バクテリア (Vibrio fischeri) による急性毒性試験を実施した 結果, 以下のことが明らかになった。

1) $\mathrm{Cd}^{2+}, \mathrm{Pb}^{2+}, \mathrm{Hg}^{2+}, \mathrm{Cr}^{6+}, \mathrm{As}^{3+}, \mathrm{As}^{5+}, \mathrm{Se}^{4+}$ は, 発光バクテリアに対して濃度依存性のあ る急性毒性影響を示した。

2 ）シアンは発光バクテリアに対して毒性影響を 示さず, 逆に発光強度の増加が認められた。 
3 ）ふっ素は発光バクテリアに対して急性毒性を 持たない。

4 ）ほう素は発光バクテリアに対する急性毒性 が非常に小さいため, 定量評価は困難である が, 急性毒性影響の閾值は土壇含有量基準值 以下であるため, スクリーニングには利用可 能であると思われる。

5 ) 六価クロムについては, 溶存形態の違い $\left(\mathrm{CrO}_{4}{ }^{2-}\right.$ 及び $\left.\mathrm{Cr}_{2} \mathrm{O}_{7}{ }^{2-}\right)$ によって発光バクテリ アに及ぼす急性毒性影響に反応速度的な差が 見られたが，曝露時間が長くなるにしたがっ て急性毒性影響の大きさ自体の差は小さく なった。

6 ) 砒素の価数（3 価及び 5 価）の違いによる急 性毒性影響の違いは比較的小さいことがわ かった。

7 ）セレンは価数の違いによって発光バクテリア に及ぼす急性毒性影響が大きく異なり，4 価 セレン（亜セレン酸）が極めて強い急性毒性 を示したのに対して，6価セレン（セレン酸） は急性毒性を全く示さなかった。

当該手法によって土䁃污染のスクリーニングを 行う場合, 土壤溶出量基準を満たせないが, 土䁃 含有量基準に関しては, $\mathrm{Pb}, \mathrm{Hg}, \mathrm{Cr}^{6+}, \mathrm{As}, \mathrm{Se}$ 及 びBについて十分に適合できる可能性があるこ とが示された。さらに, $\mathrm{Cd}, \mathrm{Pb}, \mathrm{Hg}, \mathrm{Cr}^{6+}$, $\mathrm{As}$ 及 びSeについて発光バクテリアに及ぼす急性毒性 影響の定量化を行い, 各パラメータ值を取得し た。本研究の結果から確立された一定条件下で行 われた試験から得られた值ならば, 矛盾せずに相 互利用できると考えられるため, 取得したパラ メータ值と相関式を適用することによって, 前述 の重金属等 6 種個々によって污染された土壤につ いて污染濃度を定量評価することが可能であると 考えられる。しかしながら, 本研究では, 個々の 重金属等による污染については評価可能である が, 複数の污染物質によって污染された複合污染 の評価には現状では適用できないと思われるた め, 今後は複数の重金属等によって污染された複 合污染についても評価可能なようにさらなるデー 夕の蓄積が望まれる。

\section{謝 辞}

本研究にあたり, 試料及び試験装置のご提供並 びに適切なご助言をいただきました日立化成株式 会社の皆様には, たいへんお世話になりました。 ここに感謝の意を表します。

\section{参考文献}

荒川 豊 - 野々村誠 · 栗田恵子・杉森博和 (2007a)： 海洋性発光バクテリアを用いた簡易毒性試験方法. 東京都立産業技術研究センター研究報告, 2, 110111.

荒川 豊・野々村誠・栗田恵子 (2007b) : 発光バク テリアを用いたバイオアッセイによる工場排水中 の有害物質のスクリーニング. 東京都立産業技術研 究センター平成19年度研究発表会要旨集, http:// www.iri-tokyo.jp/research/present/19/bio/bi02.pdf (2013.4.22閲覧).

北橋伸一 (2000)：マイクロトックスによる最終処分場 浸出水の毒性評価. 千葉県環境研究センター1999年 度発表資料, http://www.wit.pref.chiba.jp/bank/rd/ file/k_repo.pdf (2013.4.22閲覧).

北橋伸一 (2001)：マイクロトックスによる最終処分 場浸出水の毒性評価 (2). 千葉県環境研究センター 2000年度発表資料, http://www.wit.pref.chiba.jp/ bank/rd/file/11-8.pdf (2013.4.22閲覧).

国立環境研究所 (1998)：環境中の有機塩素化合物の 暴露量評価と複合健康評価に関する研究 (平成 4 年 度 $\sim 8$ 年度). 国立環境研究所特別研究報告書, SR25-1998.

国立環境研究所 (2001)：環境中の化学物質総リスク 評価のための毒性試験系の開発に関する研究（平成 $10 \sim 12$ 年度). 国立環境研究所特別研究報告書, SR41-2001.

国立環境研究所（2006）：化学物質環境リスクに関する 調査・研究 (平成13 17年度). 国立環境研究所特別 研究報告書, SR-76-2006.

笹島武司 - 川崎清人 ·土原義弘 - 森 友子 - 楠井隆史

佐伯真由美・橋本隆志 (2005) : 産業廃棄物最終処分 場浸出水のバイオアッセイに関する研究（第 1 報）. 平成17年度富山県環境科学センター年報, 33, 49-58. 笹島武司 · 出口 修. 平野千里 - 楠井隆史 · 橋本隆司 
荒井章寬 (2006) : 産業廃棄物最終処分場浸出水のバ イオアッセイに関する研究 (第 2 報). 平成18年度富 山県環境科学センター年報, 34, 114-119.

土䁃污染対策法 (2002) : 平成十四年五月二十九日法律 第五十三号

日本化学会 (2004) : 化学便覧 基礎編 改訂 5 版 II. 丸善, 332-333.

山川雅弘 · 水谷博和 - 前田雅也 · 早川修二 · 伊藤友夫 . 高桑三明・中谷純夫 (1998)：バイオアッセイを用 いた毒性評価について（第 3 報）一工場排水の評価 について一. 三重県環境科学センター研究報告, 18 , 9-16.

Codina, J. C., A. P.-Garcia and A. de Vicente (1994): Detection of heavy metal toxicity and genotoxicity in wastewaters by microbial assay. Water Science Technology, 30, 145-151.

Fulladosa, E., J.C. Murat, M. Martínez, I. Villaescusa (2005): Patterns of metals and arsenic poisoning in Vibrio fischeri bacteria. Chemosphere, 60, 43-48.

Gellert, G. (2000): Sensitivity and significance of luminescent bacteria in chronic toxicity testing based on growth and bioluminescence. Ecotoxicology and Environmental Safety, 45, 87-91.

Hsieh, C.-Y., M.-H. Tsai, D. K. Ryan and O. C. Pancorbo (2004): Toxicity of the 13 priority pollutant metals to Vibrio fisheri in the Microtox ${ }^{\circledR}$ chronic toxicity test, The Science of the Total Environment, 320, 37-50.

ISO (2007): ISO 11348-1 Water quality-Determination of the inhibitory effect of water samples on the light emission of Vibrio fischeri (Luminescent bacteria test)Part 1: Method using freshly prepared bacteria.

ISO (2007): ISO 11348-2 Water quality-Determination of the inhibitory effect of water samples on the light emission of Vibrio fischeri (Luminescent bacteria test)Part 1: Method using liquid-dried bacteria.
ISO (2007): ISO 11348-3 Water quality-Determination of the inhibitory effect of water samples on the light emission of Vibrio fischeri (Luminescent bacteria test)Part 1: Method using freeze-dried bacteria.

ISO (2010): ISO 21338 Water quality-Kinetic determination of the inhibitory effects of sediment, other soils and coloured samples on the light emission of Vibrio fischeri (kinetic luminescent bacteria test).

Kaiser, K. L. E. and V. Palabrica (1991): Photobacteria phosphoreum Toxicity Data Index. Water Pollution Research Journal of Canada, 26, 361-431.

McCloskey, J. T., M. C. Newman and S. B. Clark (1996): Predicting the relative toxicity of metal ions using ion characteristics: Microtox ${ }^{\circledR}$ bioluminescence assay. Environmental Toxicology and Chemistry, 15, 17301737.

McFeters, G. A., P. J. Bond, S. B. Olson and Y. T. Tchan (1983): A comparison of microbial bioassays for the detection of aquatic toxicants. Water Research, 17, 1757-1762.

Mowat, F.S. and K.J. Bundy (2002): Experimental and mathematical computational assessment of the acute toxicity of chemical mixtures from the Microtox ${ }^{\circledR}$ assay. Advances in Environmental Research, 6, 547558.

Urbanczyk, H., J. C. Ast, M. J. Higgins, J. Carson and P. V. Dunlap (2007): Reclassification of Vibrio fischeri, Vibrio logei, Vibrio salmonicida and Vibrio wodanis as Alivibrio fischeri gen. nov., comb. nov., Aliivibrio logei comb. nov., Aliivibrio salmonicida comb. nov. and Aliivibrio wodanis comb. nov., International Journal of Systematic and Evolutionary Microbiology, 57, 28232829.

(受付：2013年 4 月22日, 受理：2013年 8 月29日) 